\title{
Evolution of the arc-derived orthogneiss recorded in exotic xenoliths of the Körös Complex (Tisza Megaunit, SE Hungary)
}

\author{
Tivadar M. TÓTH*, Félix SCHUBERT \\ Department of Mineralogy, Geochemistry and Petrology, University of Szeged, H-6722 Szeged, Egyetem str. 2-6, Hungary; \\ mtoth@geo.u-szeged.hu \\ * Corresponding author
}

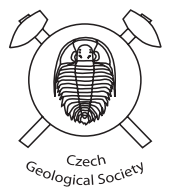

\begin{abstract}
The pre-Neogene basement of the Pannonian Basin consists of different terranes, which became juxtaposed during subsequent tectonic events from the Palaeozoic up to the Miocene. One of the largest terranes is the Tisza Megaunit, an assemblage of metamorphic blocks of different lithology and $P-T-t-d$ evolution. In the present study, petrological data from orthogneiss bodies representing numerous neighbouring crystalline highs hidden beneath sediments of the Pannonian Basin are presented.

Characteristic textures and mineral assemblages of the orthogneisses are identical in the whole studied area. Based on geochemical data, the orthogneiss precursor was quartz monzodiorite to granodiorite. The metamorphic conditions were estimated at around $580-600^{\circ} \mathrm{C}$ based on two-feldspar thermometry, co-existing amphibole-plagioclase equilibria, and Theriak/Domino modelling. The most conspicuous petrographic feature of the orthogneiss is the presence of various types of xenoliths and xenocrysts. Most xenoliths are mafic and represent eclogite and diverse amphibolite varieties, but ultramafic, carbonate, and felsic granulite also occur. All record LP-HT (low pressure, high temperature) overprint under the same conditions at which the orthogneiss formed.

Evolution of the orthogneiss body can be understood in the frame of the subduction-accretionary model. Xenoliths of various origins could represent an accretionary prism material that was picked up by the ascending granitoid melt that was subsequently solidified and metamorphosed to an orthogneiss.
\end{abstract}

Keywords: orthogneiss, Variscan, Tisza Megaunit, xenolith, eclogite, granulite Received: 31 July 2017; accepted: 10 April 2018; handling editor: P. Hasalová

\section{Introduction}

Because of its excellent hydrocarbon reservoir characteristics, hundreds of drill holes have penetrated the fractured metamorphic basement of the Tisza Megaunit (SE Pannonian Basin, Hungary) in the last decades. Despite sampling of the Variscan basement being possible only on drill cores, the most essential rock types and their $P-T$ evolution are known (e. g. Balázs et al. 1986; Szederkényi et al. 1991; Kovács et al. 2000). The orthogneiss was already recognized as the most widespread lithology in the early 1970's (Szepesházy 1973), but a comprehensive petrological study of this rock type is still missing. Because of its rather simple mineralogy, the orthogneiss was usually out of the focus whilst the other metamorphic rocks as amphibolite, micaschist and various paragneiss types were investigated (e.g. Árkai et al. 1999; Zachar et al. 2007).

Various mafic and ultramafic rocks (eclogite, amphibolite, pyroxenite and serpentinite) form enclaves in the host orthogneiss, suggesting an unusual evolution (Zachar and Tóth 2003; Tóth and Zachar 2006; Zachar et al. 2007). The enclaves exhibit contrasting metamorphic histories, especially concerning the rather wide pressure range (2-10 kbar, Zachar and Tóth 2003). The protolith of the orthogneiss was determined as granodiorite (Tóth 2008).

In the Pannonian Basin, hydrocarbon reservoirs are known to exist not only in the basin-filling Neogene sediments, but also in their underlying (presently buried) metamorphic basement. Most of these fractured basement reservoirs (Pap et al. 1992; Almási and Tóth 2000; Nelson 2001; Tari and Horváth 2006) are situated on the northern rim of the deepest sub-basin, the Békés Basin (Fig. 1b). Modelling and production of these fractured reservoirs is challenging, because the structural and geometric features of the fracture network highly determine both storage and fluid migration parameters (Vass et al. 2018). When studying fracture systems of the most common gneiss and amphibolite varieties in the metamorphic basement of the Pannonian Basin, Tóth et al. (2004) proved that the fracture geometry is highly dependent on the lithology, and, compared to other rock types, orthogneiss is usually purely fractured. Importantly, the huge orthogneiss bodies are characterized by unconnected fracture networks which separate rock bodies with good reservoir qualities.

Better understanding of the metamorphic and structural evolution of the orthogneiss is therefore crucial for 
the reconstruction of the Tisza Megaunit history as well as for its reservoir geology. The area investigated in this study is the most elevated chain of metamorphic highs north of the Békés Basin (Fig. 1b), where hundreds of drillings into the metamorphic basement were sampled.

\section{Geological setting}

\subsection{Pannonian Basin}

The Tisza Megaunit forms the crystalline basement of southern Hungary; it is located between the Mid-Hungarian Line and the Maros Zone; the latter separates it from the Southern Carpathians (Fig. 1). According to the currently accepted model (Csontos et al. 1992), the Tisza Megaunit forms a single Alpine terrane, which was detached from the northern, European margin of the Tethys in the Middle Jurassic (Bathonian). It consists essentially

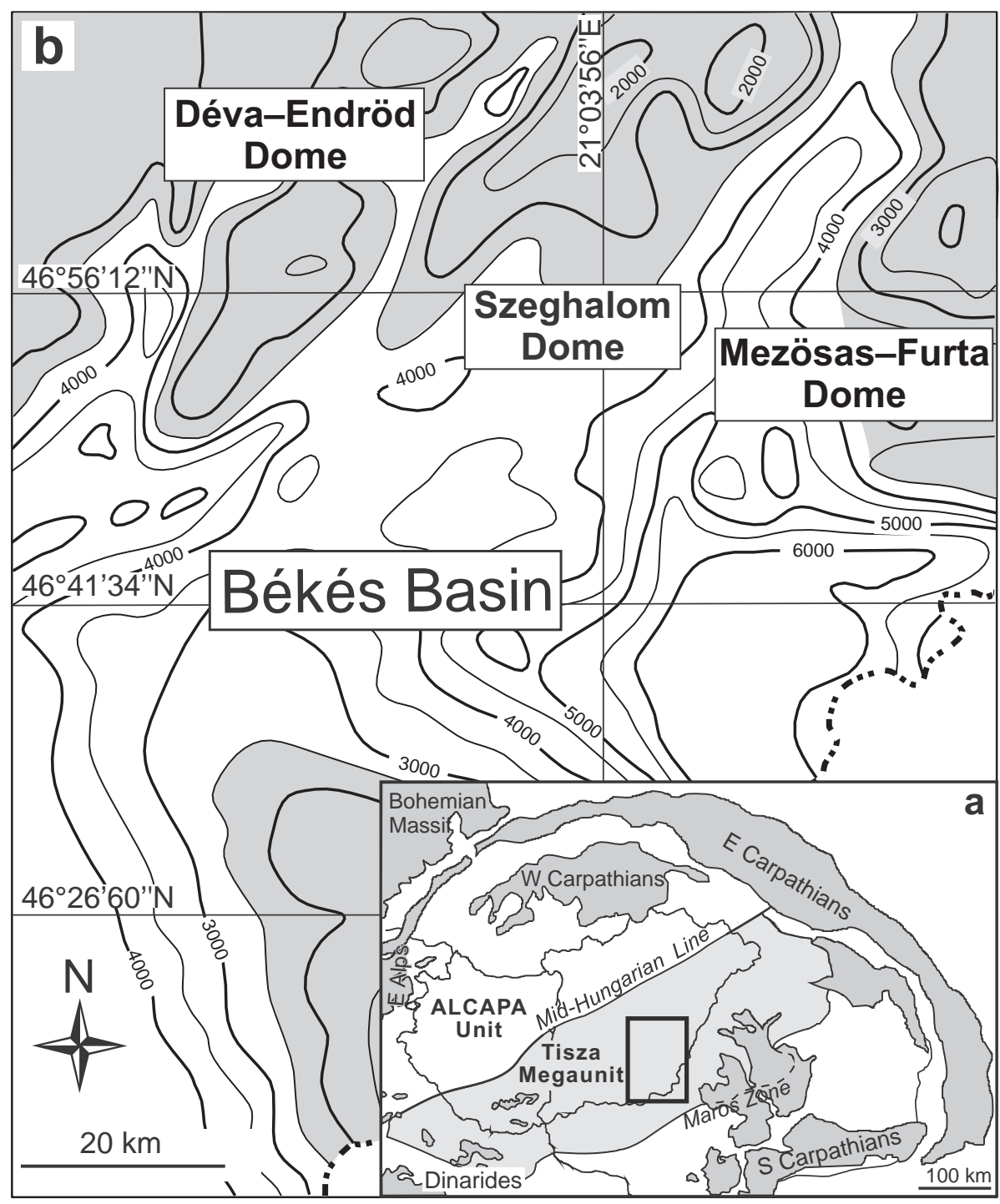

of Variscan metamorphic rocks covered by Tertiary and younger sediments of hundreds to, in the eastern part, thousands of metres thickness.

During the formation of the Pannonian Basin in Neogene, major horizontal and vertical fault zones were active inside the crystalline basement. The syn-rift phase of the basin subsidence history caused development of metamorphic core complexes, as proved by seismic and fission-track geochronological data (Posgay et al. 1996; Tari et al. 1999). Simultaneously with the main basin subsidence phase during the middle Miocene, a significant WSW-ENE striking sinistral strike-slip fault zone was active inside the study area; negative flower structures can be followed on the seismic profiles from the basement up to the basin filling sediments (Albu and Pápa 1992). As a result of the last stage of the extension, the basement now forms a series of N-S-striking horstgraben structures.

Due to the multistage evolution of the Pannonian Basin, the present morphology of its pre-Neogene basement is rather complicated, exhibiting topographic highs surrounding deep sub-basins (Fig. 1b). One of the deepest basins is the Békés Basin, which has a maximal depth of $c .6 \mathrm{~km}$ beneath the present surface. Even the most elevated topographic maxima north of it are covered by some $2 \mathrm{~km}$ of sediments, which means that petrographic examination is only possible on drill cores.

\subsection{Körös Complex}

The uplifted, but still buried part of the metamorphic basement in this region is known as Körös Complex. All basement highs have rather complex lithology and structure, essentially due to the complicated tectonic evolution (Pogácsás et al. 1989; Posgay and Szentgyörgyi 1991; Albu and Pápa 1992; Tari et al. 1992, 1999; Lörincz 1996).

Fig. 1a Location of the Tisza Megaunit in the Alpine-Carpathian-Dinaric system. $\mathbf{b}$ - Topographic map of the Békés Basin and its surrounding basement highs. Isolines denote depth below the present surface (in $\mathrm{m}$ ). 
Typical gneiss and amphibolite varieties of the whole area are best known in the central highs (Déva-Endröd Dome - DED, Szeghalom Dome - SzD, Mezösas-Furta Dome - MFD, Fig. 1b), where rock specimens from almost 200 drill cores are available for petrological investigation. Previous studies (Balázs et al. 1986; Szederkényi et al. 1991) suggested that the main lithologies are identical as in all neighbouring highs. Based on these results, the basement in the study area can be divided into three realms separated by postmetamorphic tectonic zones (Tóth et al. 2000).

As an example, geological map of the easternmost crystalline high, Mezösas-Furta Dome is shown in Fig. 2. In the south, the lowermost orthogneiss zone is known only from the core material of the deepest drillings, and essentially the two upper units form the basement (Fig. 2). The middle structural realm is a sillimanite- and garnet-bearing paragneiss-dominated block (SG unit, Fig. 2), while the uppermost one consists of amphibole-biotite orthogneiss and amphibolite (AG unit, Fig. 2). These two upper blocks exhibit remarkably different metamorphic evolutions and so must have been juxtaposed later during post-metamorphic tectonic events. This is also supported by the fact that the contacts between the two units rims a wide tectonic breccia and cataclasite zone with a total thickness of several tens of metres (Tóth et al. 2000, 2008, 2010; Molnár et al. 2015). Along the wide shear

Fig. 2a - Geological map of the Mezösas-Furta Dome. b - Selected A-A' cross section. Black dots represent boreholes that penetrated the metamorphic basement (following Tóth and Zachar 2006). Drillings are denoted by dots. Those, in which orthogneiss contains the most xenoliths are named. zone intensive hydrothermal alteration of the overlying AG block is evident.

Amphibole-biotite orthogneiss is a typical rock type in the whole study area at the topmost structural level. This lithology is characterized by interlocking centimetrethick layers of amphibolite, amphibole-biotite or, in
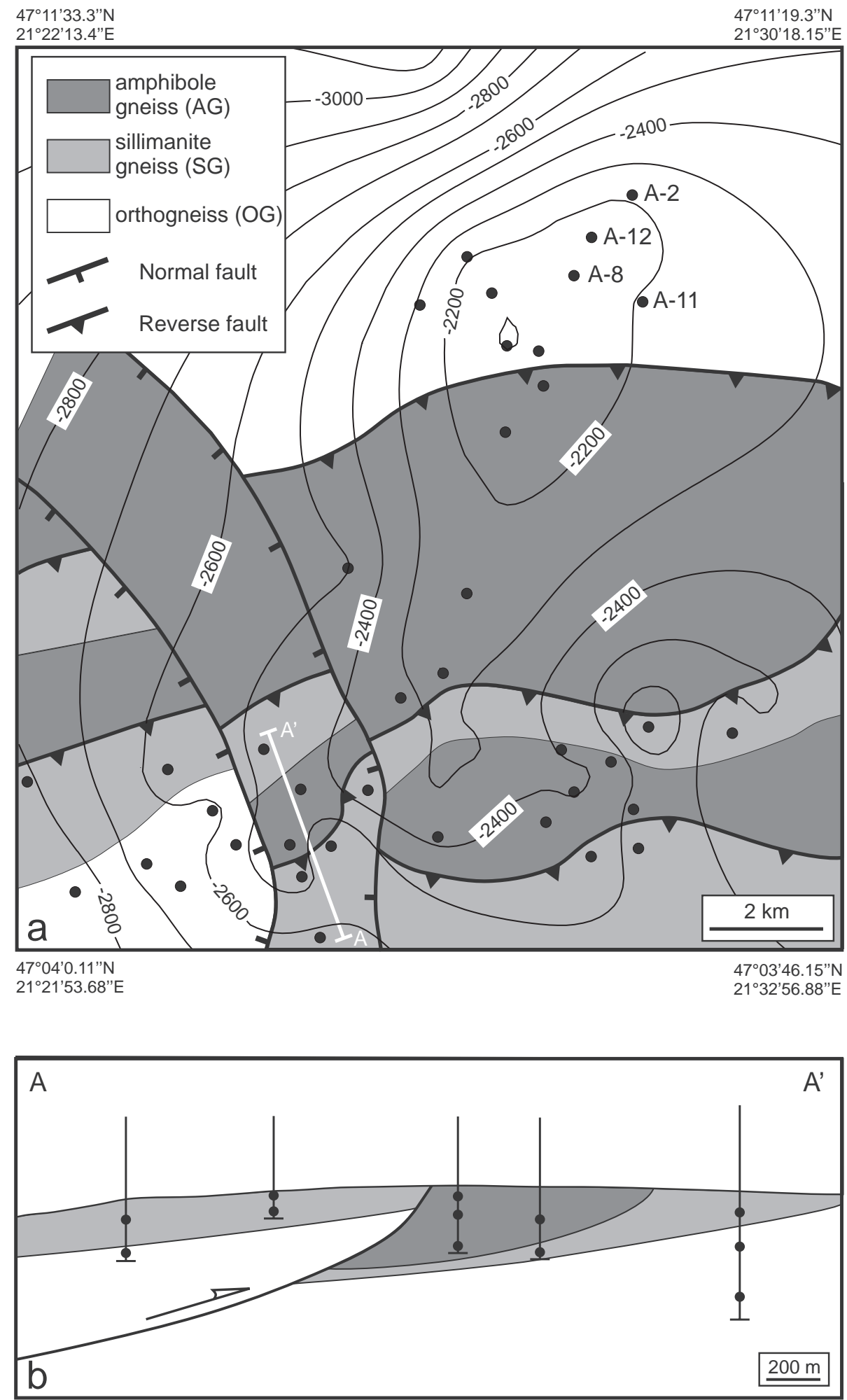
places, biotite orthogneiss. Amphibole-bearing subtypes commonly contain quartz, epidote and ilmenite in addition to the rock-forming amphibole and plagioclase, while tiny garnet grains appear only in a few samples. For amphibole-plagioclase pairs, similar $P-T$ data can be calculated by diverse approaches (Tóth 2008). The method of Holland and Blundy (1994) gives $550-570^{\circ} \mathrm{C}$, that of Gerya et al. (1997) $560^{\circ} \mathrm{C}$ at $3-4 \mathrm{kbar}$, while that of Plyusnina (1982) results in $530^{\circ} \mathrm{C}$ at 4 kbar.

Sillimanite paragneiss of the middle structural zone consists essentially of quartz, two feldspars, biotite and fibrolitic sillimanite; muscovite is absent. Most samples display two fabrics: $\mathrm{S}_{1}$ is largely interfolial to the penetrative $S_{2}$. The $S_{1}$ is defined by resorbed garnet grains as well as biotite and kyanite laths, while sillimanite and biotite delineate the $\mathrm{S}_{2}$. In sillimanite gneiss, the complete $P-T$ path was determined (Tóth 2008). Biotite inclusions together with garnet cores suggest peak temperature of $730-750^{\circ} \mathrm{C}$ (Bhattacharya et al. 1992), while using GASP paragenesis assuming co-existent kyanite, the pressure is 7.5-7.8 kbar (Tóth 2008). Using the same equilibria for matrix assemblages, the temperature is $630-650^{\circ} \mathrm{C}$; pressure varies between 4 and 5 kbars.

In the deepest zones in the southern part of the crystalline highs as well as in the entire northern slopes (Fig. 2), the AG and SG rock types do not occur. These areas are characterized by intensely tectonized, coarse-grained biotite orthogneiss. Szepesházy (1973) already called attention to the special texture of this rock type and found it to be orthogneiss (OG unit). Although this rock type is rather widespread in the whole area, so far only very limited information is available about its petrological and structural evolution.

Table $1 \mathrm{~K}$-Ar age data from the orthogneiss and its amphibolite xenoliths (Balogh et al. 2009)

\begin{tabular}{lccc}
\hline Borehole & Sample & Mineral & K-Ar age \\
\hline Sz-40 & amphibolite xenolith & Amphibole & $316 \pm 13$ \\
Sas-4 & amphibolite xenolith & Amphibole & $329 \pm 13$ \\
Bih-Ú-3 & amphibolite xenolith & Amphibole & $334 \pm 13$ \\
Sz-15 & xenocryst & Amphibole & $302 \pm 12$ \\
Sz-15 & xenocryst & Amphibole & $291 \pm 12$ \\
Fü-6 & xenocryst & Amphibole & $289 \pm 11$ \\
Sz-É-3 & xenocryst & Amphibole & $293 \pm 10$ \\
Föl-10 & xenocryst & Amphibole & $311 \pm 12$ \\
En-É-7 & orthogneiss matrix & Biotite & $325 \pm 13$ \\
Sz-Ny-1 & orthogneiss matrix & Biotite & $319 \pm 12$ \\
Köl-4 & orthogneiss matrix & Biotite & $295 \pm 11$ \\
Sz-É-8 & orthogneiss matrix & Biotite & $295 \pm 11$ \\
Déva-7 & orthogneiss matrix & Biotite & $296 \pm 11$ \\
Sz-15 & orthogneiss matrix & K-feldspar & $187 \pm 7$ \\
Sz-Ny-1 & orthogneiss matrix & K-feldspar & $180 \pm 7$ \\
Fü-6 & orthogneiss matrix & K-feldspar & $194 \pm 11$ \\
Sz-É-11 & orthogneiss mylonite & Muscovite & $280 \pm 11$ \\
\hline
\end{tabular}

\subsection{K-Ar geochronology}

There are a few well-documented $\mathrm{K}$-Ar age data available in unpublished industry reports corresponding to the Körös orthogneiss (Balogh et al. 2009; Tab. 1). Biotite from three orthogneiss samples yielded Permian ages $(295 \pm 11 \mathrm{Ma})$ similar to those measured in five amphibole xenocrysts $(297 \pm 11 \mathrm{Ma})$. The amphibolite xenoliths are significantly older, with $\mathrm{K}-\mathrm{Ar}$ amphibole ages between $316 \pm 13$ and $334 \pm 13$ Ma. K-feldspar K-Ar age data are $187 \pm 9 \mathrm{Ma}$, which is comparable to those measured in the overlying

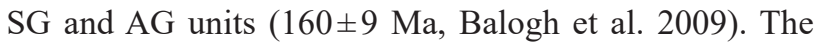
$\mathrm{K}$-Ar age of muscovite from the most intensively deformed orthogneiss mylonite sample is $280 \pm 11 \mathrm{Ma}$.

\subsection{Structural evolution}

Not much is known about the post-Variscan exhumation of the basement, south and north of the uplifted series of domes as Permian to Cretaceous sediments cover the unknown metamorphic mass. The effect of Early Jurassic rifting is documented exclusively by a few zircon fissiontrack and (U-Th)/He age data (Balogh et al. 2009). During the Late Cretaceous compressional activity, nappes formed (Tari et al. 1999), causing significant sub-horizontal shearzones inside the pre-Neogene basement. As a result of this major overthrusting episode, slivers of diverse tectonic blocks and Mesozoic cover units alternate in the basement (Tari and Horváth 2006). Based on current seismic interpretations the breccia zone separating the SG and AG units can be explained as overthrust horizon of this Cretaceous tectonic event (Tóth et al. 2008; Molnár et al. 2015, Fig. 2).

Multistage evolution of the Pannonian Basin during the Neogene, which coincided with exhumation of the metamorphic basement, was responsible for brittle deformation of the crystalline rocks. Recent studies from the Szeghalom Dome document the final uplift of the metamorphic basement during the Neogene, inferred from the systematically decreasing fluid-inclusion $T_{\max }$ values in the subsequent fracture-filling minerals (Juhász et al. 2002; Schubert et al. 2007). Final calcite phase precipitated at $c .50^{\circ} \mathrm{C}$ and encloses pollen of Neogene terrestrial vegetation, timing the final exhumation (Juhász et al. 2002; Tóth et al. 2003). The same pollen-bearing calcite occurs in both the northern as well as southern realms of the Szeghalom Dome, suggesting a similar Neogene exhumation history. Following the most exhumed position of the basement, the area subsided again, being at about $2 \mathrm{~km}$ depth at present.

\section{Analytical techniques}

Samples studied and discussed in this paper represent core material of boreholes (total number of 60) that 
Table 2 Representative whole-rock major- (wt. \%) and trace-element (ppm) compositions of the orthogneiss

\begin{tabular}{|c|c|c|c|c|c|c|c|c|c|}
\hline & OG1 & OG2 & OG3 & OG4 & OG5 & OG6 & OG7 & OG8 & OG9 \\
\hline $\mathrm{SiO}_{2}$ & 64.38 & 54.60 & 54.16 & 64.16 & 59.87 & 63.17 & 62.12 & 57.30 & 61.58 \\
\hline $\mathrm{TiO}_{2}$ & 0.64 & 0.93 & 0.89 & 0.81 & 0.85 & 0.83 & 0.74 & 0.90 & 0.86 \\
\hline $\mathrm{Al}_{2} \mathrm{O}_{3}$ & 15.46 & 16.32 & 15.29 & 14.60 & 16.63 & 16.13 & 16.82 & 16.62 & 11.08 \\
\hline $\mathrm{Fe}_{2} \mathrm{O}_{3}$ & 4.32 & 8.24 & 9.57 & 6.76 & 6.29 & 5.91 & 5.61 & 8.13 & 9.42 \\
\hline $\mathrm{MnO}$ & 0.05 & 0.14 & 0.12 & 0.11 & 0.11 & 0.12 & 0.13 & 0.09 & 0.20 \\
\hline $\mathrm{MgO}$ & 1.62 & 4.17 & 4.36 & 2.48 & 2.57 & 2.63 & 2.35 & 4.74 & 4.52 \\
\hline $\mathrm{CaO}$ & 2.96 & 4.89 & 3.81 & 1.03 & 2.52 & 3.17 & 4.31 & 2.46 & 6.58 \\
\hline $\mathrm{Na}_{2} \mathrm{O}$ & 4.60 & 3.38 & 4.53 & 4.30 & 5.20 & 5.14 & 5.13 & 4.50 & 3.27 \\
\hline $\mathrm{K}_{2} \mathrm{O}$ & 2.47 & 4.51 & 1.64 & 1.68 & 2.31 & 2.32 & 2.42 & 2.27 & 0.87 \\
\hline $\mathrm{P}_{2} \mathrm{O}_{5}$ & 0.19 & 0.18 & 0.15 & 0.15 & 0.24 & 0.21 & 0.19 & 0.19 & 0.22 \\
\hline LOI & 2.03 & 2.50 & 5.20 & 4.43 & 1.87 & 1.41 & 1.02 & 2.39 & 0.60 \\
\hline Sum & 98.72 & 99.86 & 99.72 & 100.64 & 98.46 & 101.04 & 100.84 & 99.59 & 99.20 \\
\hline $\mathrm{Cr}$ & 49 & 182 & 157 & 28 & 45 & 32 & 33 & 150 & 331 \\
\hline $\mathrm{Ni}$ & 21 & 48 & 51 & 25 & 15 & 13 & 14 & 64 & 106 \\
\hline Co & 10 & 22 & 20 & 10 & 10 & 14 & 11 & 24 & 25 \\
\hline V & 76 & 193 & 256 & 126 & 114 & 94 & 96 & 196 & 134 \\
\hline $\mathrm{Cu}$ & 51 & 100 & 103 & 74 & 82 & 75 & 69 & 113 & 140 \\
\hline $\mathrm{Pb}$ & 1.6 & 0.5 & 2.2 & 5.8 & 3.5 & 4.2 & 3.6 & $<2.0$ & 2.0 \\
\hline $\mathrm{Zn}$ & 4 & 29 & 27 & 149 & 4 & 8 & 2 & 44 & 1 \\
\hline $\mathrm{Rb}$ & 44 & 138 & 53 & 62 & 78 & 55 & 81 & 62 & 13 \\
\hline $\mathrm{Ba}$ & 795 & 1156 & 945 & 499 & 758 & 814 & 570 & 531 & 91 \\
\hline $\mathrm{Sr}$ & 630 & 358 & 265 & 328 & 261 & 297 & 331 & 412 & 258 \\
\hline $\mathrm{Ga}$ & 19.4 & 18.7 & 18.3 & 17.9 & 20.8 & 16.3 & 18.9 & 20.4 & 22.4 \\
\hline $\mathrm{Nb}$ & 14 & 8 & 4 & 8 & 6 & 8 & 10 & 7 & 21 \\
\hline $\mathrm{Zr}$ & 217 & 144 & 142 & 145 & 257 & 198 & 166 & 140 & 108 \\
\hline $\mathrm{Y}$ & 15 & 36 & 19 & 23 & 26 & 30 & 34 & 29 & 27 \\
\hline Th & 7 & 9 & 6 & 21 & 5 & 11 & 5 & 9 & 4 \\
\hline $\mathrm{U}$ & 11.2 & 3.2 & 1.1 & 3.3 & 4.0 & 7.7 & 4.2 & 1.2 & $<1.0$ \\
\hline
\end{tabular}

penetrated the orthogneiss-dominated, deepest structural unit of the three neighbouring basement highs (Déva-Endröd, Szeghalom and Mezösas-Furta domes, Figs 1 and 2).

\subsection{Raman spectrometry}

Raman spectrometry was used to identify tiny relict mineral grains. Measurements were performed on a Thermo Scientific DXR Raman microscope at the Department of Mineralogy, Geochemistry and Petrology of the University of Szeged using a diode-pumped frequency-doubled $\mathrm{Nd}$-YAG laser at $10 \mathrm{~mW}$ maximum laser power and a laser light with a wavelength of $532.2 \mathrm{~nm}$.

\subsection{Whole-rock geochemistry}

The whole-rock composition of the orthogneiss samples was measured using an automated Philips PW1453 $\mathrm{X}$-ray fluorescence spectrometer with a Sc-Mo tube at the XRF laboratory of University of Fribourg (Switzerland). Major elements were determined from discs fused in a $\mathrm{Pt}$ crucible using $\mathrm{Li}_{2} \mathrm{~B}_{4} \mathrm{O}_{7}$ flux at $1000^{\circ} \mathrm{C}$. The following trace elements were measured in the pressed disks: $\mathrm{V}, \mathrm{Cr}$,
$\mathrm{Ni}, \mathrm{Ga}, \mathrm{Zr}, \mathrm{Y}, \mathrm{Nb}, \mathrm{Rb}, \mathrm{Sr}$, and $\mathrm{Ba}$. Natural standards were used for the measurement. Both major and trace element data have a relative precision better than $2 \%$.

\subsection{Mineral chemistry}

Mineral chemistry was obtained using the Cameca SX-50 electron microprobe at the University of Bern (Switzerland). Synthetic and natural standards were used; the conditions were $15 \mathrm{kV}$ and $20 \mathrm{nA}$. On-line data reduction was carried out using the PAP method. Mineral names are abbreviated following Whitney and Evans (2010).

\subsection{Thermobarometry}

In addition to applying traditional thermometers and barometers, the stability field of the peak metamorphic parageneses was modelled by the Theriak/Domino (de Capitani 1994; de Capitani and Petrakakis 2010) and TWQ (Berman, 1991) programs. The thermodynamic database used for modelling was an extended version of Berman (1988) with modifications from Meyre et al. (1997). The complete database can be obtained from the authors. 


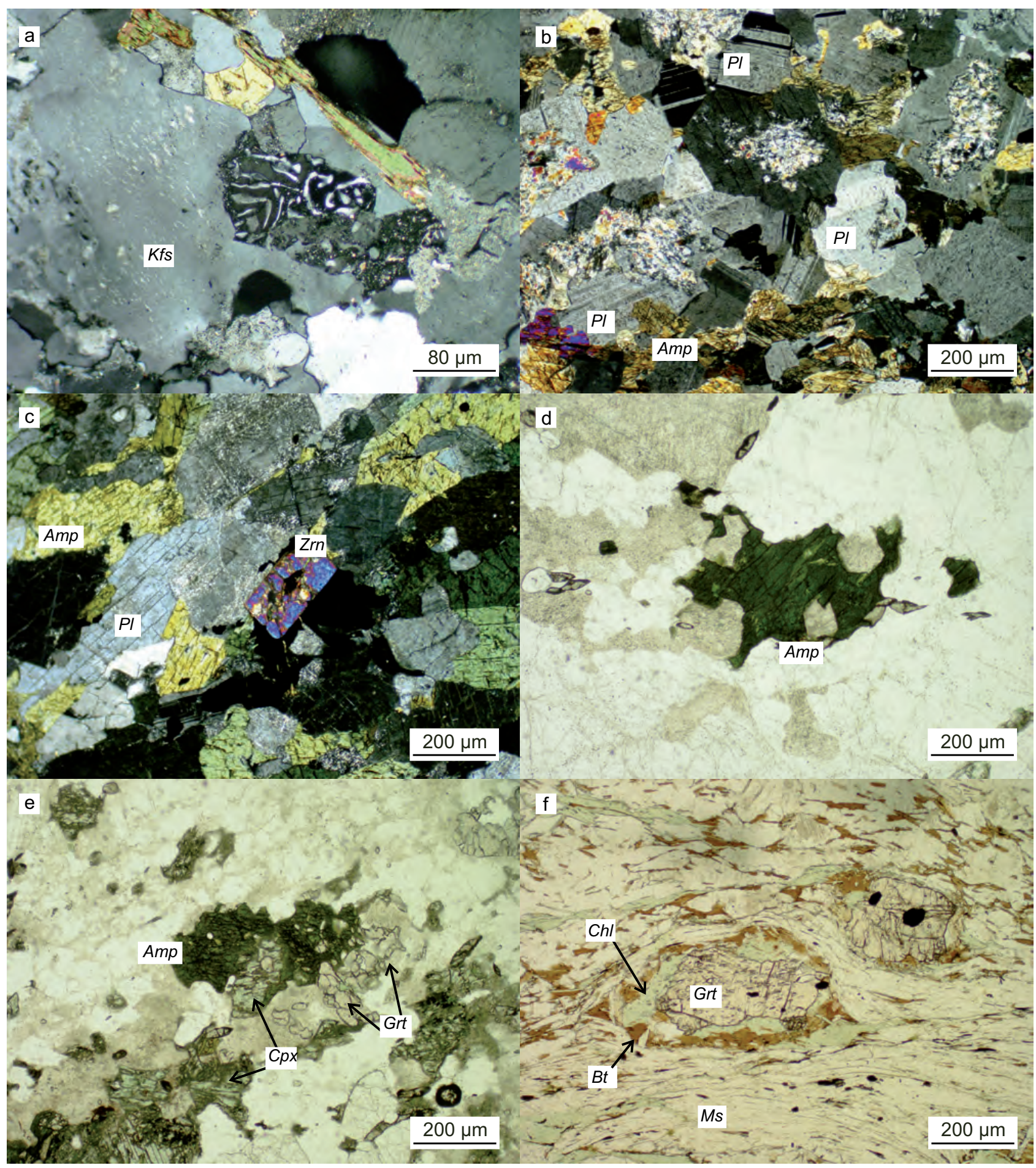

Fig. 3 Photomicrographs of the studied orthogneisses. a - Relict myrmekitic inclusion in a matrix K-feldspar grain (XPL, northern slope of SzD, Fig. 1). $\mathbf{b}$ - Quartz and feldspar preserve polygonal texture (XPL, northern slope of SzD, Fig. 1). c - Idiomorphic zircon grain in the matrix of the orthogneiss (XPL, northern slope of DED, Fig. 1). d - Resorbed amphibole xenocryst with wiggly grain boundaries (PPL, A-11, Fig. 2). e Amphibole, clinopyroxene and garnet xenocrysts in the orthogneiss matrix (PPL, A-12, Fig. 2). $\mathbf{f}-$ Chloritized garnet xenocryst surrounded by fresh biotite (northern slope of SzD, Fig. 1).

In the first step of $P-T$ modelling, muscovite-bearing orthogneiss samples were evaluated in the CNKFMASH system for bulk rock compositions given in Tab. 2. All measured LOI was assumed to be $\mathrm{H}_{2} \mathrm{O}$. Epidote, clino- zoisite, titanite, kyanite and biotite were treated as ideal, while Ganguly and Saxena's model (1984) was applied for garnet, Chatterjee and Froese's (1975) for white mica and Fuhrman and Lindsley's (1988) for feldspar. 


\subsection{Deformation history}

In monomineralic domains of quartz-rich metamorphic rocks, the geometry of grain boundaries is a function of temperature and deformation history (Kruhl and Nega 1996; Takahashi et al. 1998). Fractal geometry is an adequate tool to determine the complexity of these boundaries. Among the possible approaches, Kruhl and Nega (1996) applied a ruler method to measure the fractal dimension of the sutures and used the D-value (the socalled "ruler dimension"; Mandelbrot 1967; Majumder and Mamtani 2009) to calibrate a thermometer. The method was later refined by Takahashi et al. (1998). Although complexity of grain boundaries is also a function of shear rate, formation temperature can be estimated using this approach; the more segmented quartz-quartz sutures result in a higher fractal dimension thus lower temperature.

Measurements were made on photomicrographs taken with a 6-megapixel digital camera mounted on an Olympus BX-41 microscope. Each suture was magnified $500 \times$ following the suggestions of Kruhl and Nega (1996). After digital recording and contrasting, the images were saved as a one-pixel-thick white line in a bitmap file. For numerical evaluation, the ruler dimension option of the Benoit 1.0 software (TruSoft 1997) was used.

\section{Results}

\subsection{Petrography}

\subsubsection{Orthogneiss}

The orthogneiss samples are rather homogeneous with regard to both mineralogical and textural features throughout the study area (Fig. 3). Mineral assemblage of $\mathrm{K}$-feldspar, plagioclase, quartz, biotite and muscovite is identical in all localities (Fig. 3a-b). Accessory phases are idiomorphic zircon (Fig. 3c) and apatite with minor tourmaline and allanite. A detailed SEM study shows that zircon regularly contains tiny apatite and quartz inclusions.

The studied orthogneiss is monometamorphic and has a single foliation $\left(\mathrm{S}_{1}\right)$ defined by biotite, quartz ribbons, elongated feldspar porphyroclasts and, in cases, muscovite bunches (Fig. 3f). Matrix feldspars usually contain myrmekitic inclusions (Fig. 3a) and rarely form a polygonal texture (Fig. 3b). The straight grain boundaries as well as the $\sim 120^{\circ}$ junctions suggest either $H T$ recrystallization or intrusive igneous origin. Myrmekite occurs in different textural positions (Zachar and Tóth 2001); either it grows at the contact between matrix plagioclase and
$\mathrm{K}$-feldspar grains, or, the most commonly, it forms sericitic inclusions in fresh K-feldspar grains (Fig. 3a). In these places, apophyses of the fresh host mineral (microcline) are advancing into the sericitic myrmekite, separating relics of the old myrmekitic feldspar (Fig. 3a). Myrmekitic inclusions are generally xenomorphic in shape. The arrangement of myrmekite in the samples studied does not indicate any orientation.

\subsubsection{Xenocrysts}

The orthogneiss contains various types of xenoliths and/ or xenocrysts (Zachar and Tóth 2003). The most common xenocrysts are amphibole (Fig. 3b-e), garnet and clinopyroxene (Fig. 3e). Amphibole xenocrysts usually form large tabular crystals, in cases with clinopyroxene and garnet inclusions (Fig. 3e). The arrangement of the amphibole grains shows no orientation. They form randomly oriented anhedral to subhedral grains in the polygonal quartz-feldspar matrix of the orthogneiss (Fig. 3d-e). Amphibole is always resorbed with wiggly grain boundaries (Fig. 3d). In the Ca-rich domains of the amphibole xenocryst-bearing orthogneiss samples, epidote and titanite occur. The resorbed garnet grains with S-shaped inclusion trails are rather common in the polygonal texture of feldspar and quartz of the orthogneiss. Clinopyroxene usually occurs together with amphibole and sometimes garnet xenocrysts (Fig. 3e). All of these grains and textural elements define domains that are chemically significantly different from the host orthogneiss.

\subsubsection{Xenoliths}

For the orthogneiss, not only different xenocrysts but also a wide spectrum of xenoliths is characteristic. Because only drill-core samples are available, it is hard to estimate the shape, size and orientation of these xenoliths. While the $10-20 \mathrm{~cm}$ small pieces can clearly be outlined in hand specimens, others may reach even $10 \mathrm{~m}$, suggested by their homogeneous composition along some drill cores. Most xenoliths are mafic in composition (amphibolite or eclogite), but serpentinite and anthophyllite schist and a few marbles and a single felsic granulite were found as well. The drillings in which orthogneiss contains the most xenoliths are denoted in Fig. 2a.

Whenever the contact between mafic enclaves and the host orthogneiss can be studied in the core material, continuous transition is obvious (Fig. 4a). In the orthogneiss, few centimetres from the contact, the amount of amphibole, clinopyroxene, and garnet grains decreases and their grain boundaries become serrated. In samples from several boreholes the whole spectrum of different enclaves occurs. 


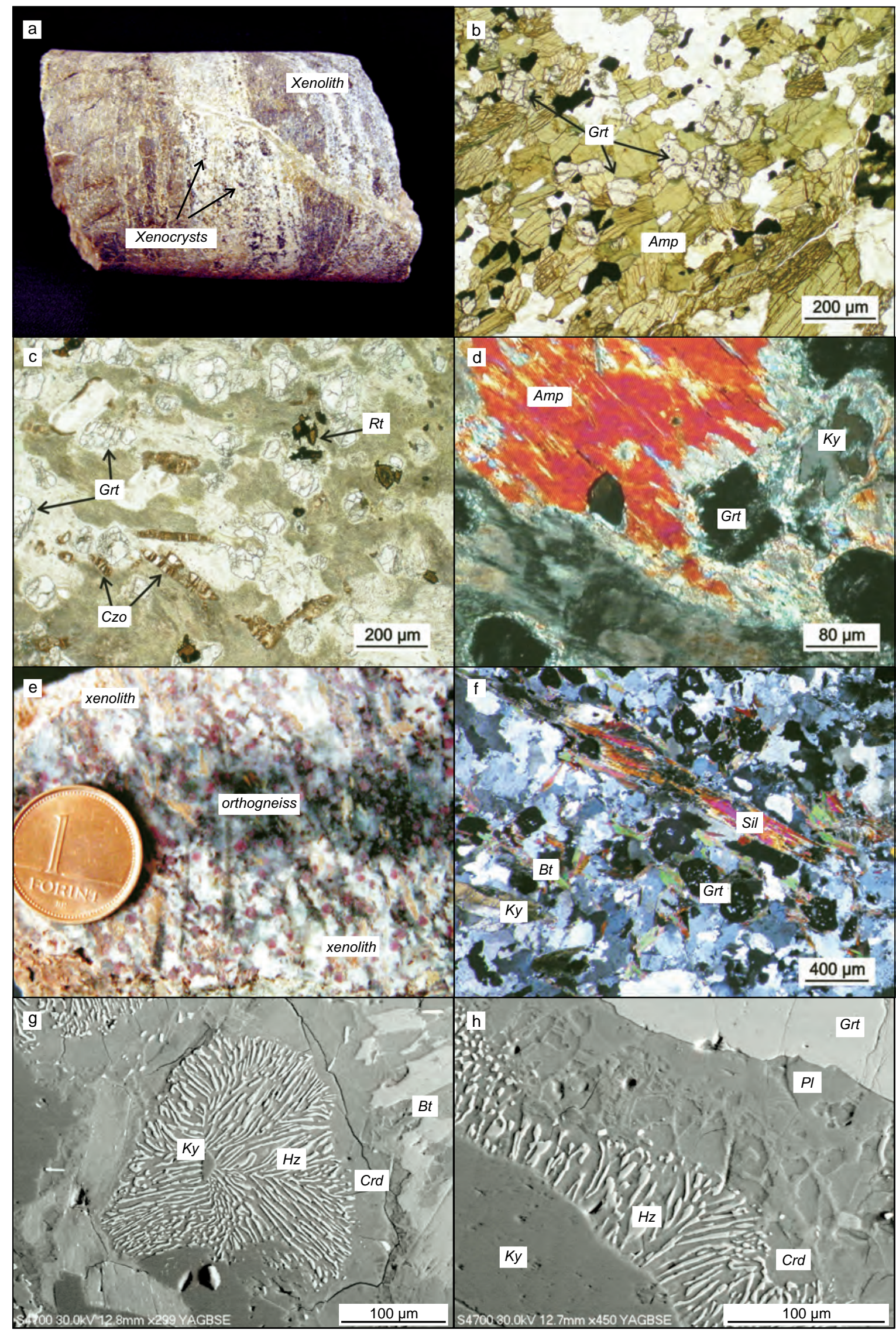


The most common xenolith variety is a garnet-bearing amphibolite (Fig. 4b). It consists essentially of tightly packed amphibole grains, garnet, small amount of plagioclase and in places even clinopyroxene inclusions. The generalized peak assemblage is $\mathrm{Amp}+\mathrm{Pl} \pm \mathrm{Grt} \pm \mathrm{Cpx} \pm \mathrm{Rt}$.

The texture of the eclogite xenoliths is symplectitic, but all preserve mineralogical and textural relics of an early HP record (Fig. 4c). The original eclogite assemblage $\left(\mathrm{M}_{1}\right)$ can be reconstructed as $\mathrm{Cpx}+\mathrm{Grt}+\mathrm{Rt} \pm \mathrm{Ky} \pm \mathrm{Ph} \pm \mathrm{Czo}$. Around $30 \%$ of the least retrogressed eclogite sample consists of garnet that encloses tiny kyanite and rutile inclusions. Garnet grains are surrounded by a fine-grained corona of Amp $+\mathrm{Pl}$. Clinopyroxene is almost entirely replaced by the fine symplectite; kyanite and phengite are surrounded by margarite rims. The rock texture indicates a metamorphic overprint $\left(\mathrm{M}_{2}\right)$ following the decomposition of the original eclogite to symplectite: large amphibole laths enclose garnet, kyanite, and phengite grains together with their symplectitic coronas (Fig. 4d). The $\mathrm{M}_{2}$ paragenesis also contains plagioclase; the stable Ti-phase is ilmenite.

Another type of the eclogite xenoliths is more symplectitic and contains similar HP relicts (Grt, Ph, Ky, Rt), but amphibole porphyroblasts do not contain inclusions, and, according to textural evidence, their growth predated the symplectite formation (Tóth 1995).

Felsic rock types are usually not present as xenoliths in the orthogneiss. The only exception is a single felsic granulite sample (Fig. 4e), which consists of Qz, Pl, Kfs, $\mathrm{Bt}$, Grt, Ky, Amp and Rt. The contact of the granulite xenolith and the host orthogneiss can be observed in the drill core. It is not tectonic, as the orientation of late biotite flakes of the xenolith is identical to the foliation of the orthogneiss (Fig. 4e). In the xenolith, textural relics of several former phases are preserved. Traces of the earliest event $\left(\mathrm{M}_{1}\right)$ are present as inclusions $(\mathrm{Qz}, \mathrm{Ky}, \mathrm{Ms}, \mathrm{Pl}$, Afs, Rt, and Zrn) in the small, equally sized garnet grains. The $\mathrm{M}_{2}$ event is characterized by Qz, Kfs, Pl, Grt, Rt and Ky assemblage. During the $M_{3}$ event, bunches of large prismatic sillimanite as well as biotite flakes formed, both

Fig. 4 Macro- and micro-photos of the xenoliths. a-Continuous transition between the mafic xenolith and the host orthogneiss (A-8, Fig. 2); length of the core is $\sim 20 \mathrm{~cm}$. $\mathbf{b}$ - Matrix of a garnetiferous amphibolite xenolith formed of amphibole, plagioclase and garnet (PPL, A-11, Fig. 2). c - Symplectitic texture of a typical eclogite xenolith (PPL, northern slope of DED, Fig. 1). d - Relict HP phases, garnet and kyanite are enclosed in large amphibole laths together with their symplectitic coronas (XPL, northern slope of DED, Fig. 1). e - Intrusive contact between the felsic granulite xenolith and the host orthogneiss (northern slope of SzD, Fig. 1). $\mathbf{f}-$ Sillimanite and biotite in the granulite define foliation identical to that of the host orthogneiss (XPL, northern slope of SzD, Fig. 1). $\mathbf{g}$ - In contact with biotite, kyanite is rimmed by a spinel and cordierite corona (northern slope of SzD, Fig. 1). h - Cordierite and plagioclase appear at the kyanite-garnet contact (northern slope of SzD, Fig. 1). oriented parallel to the foliation of the host orthogneiss (Fig. 4f). Kyanite is surrounded by complex coronas, although the mineral composition of these textures depends essentially on the neighbouring phases. Near biotite, the kyanite is rimmed by an inner $\mathrm{Crd}+\mathrm{Spl}$ and an outer pure Crd corona (Fig. 4g). In several cases kyanite itself appears as a pseudomorph and is replaced by a set of tiny undeterminable phyllosilicate grains of pale green colour in plane-polarized light. At a garnet-kyanite contact, garnet porphyroblasts are rimmed by plagioclase, while kyanite is surrounded by a $\mathrm{Crd}+\mathrm{Spl}$ corona. Along the border of the two different reaction rims, a special mesh texture formed by $\mathrm{Crd}+\mathrm{Pl}$ appears (Fig. 4h).
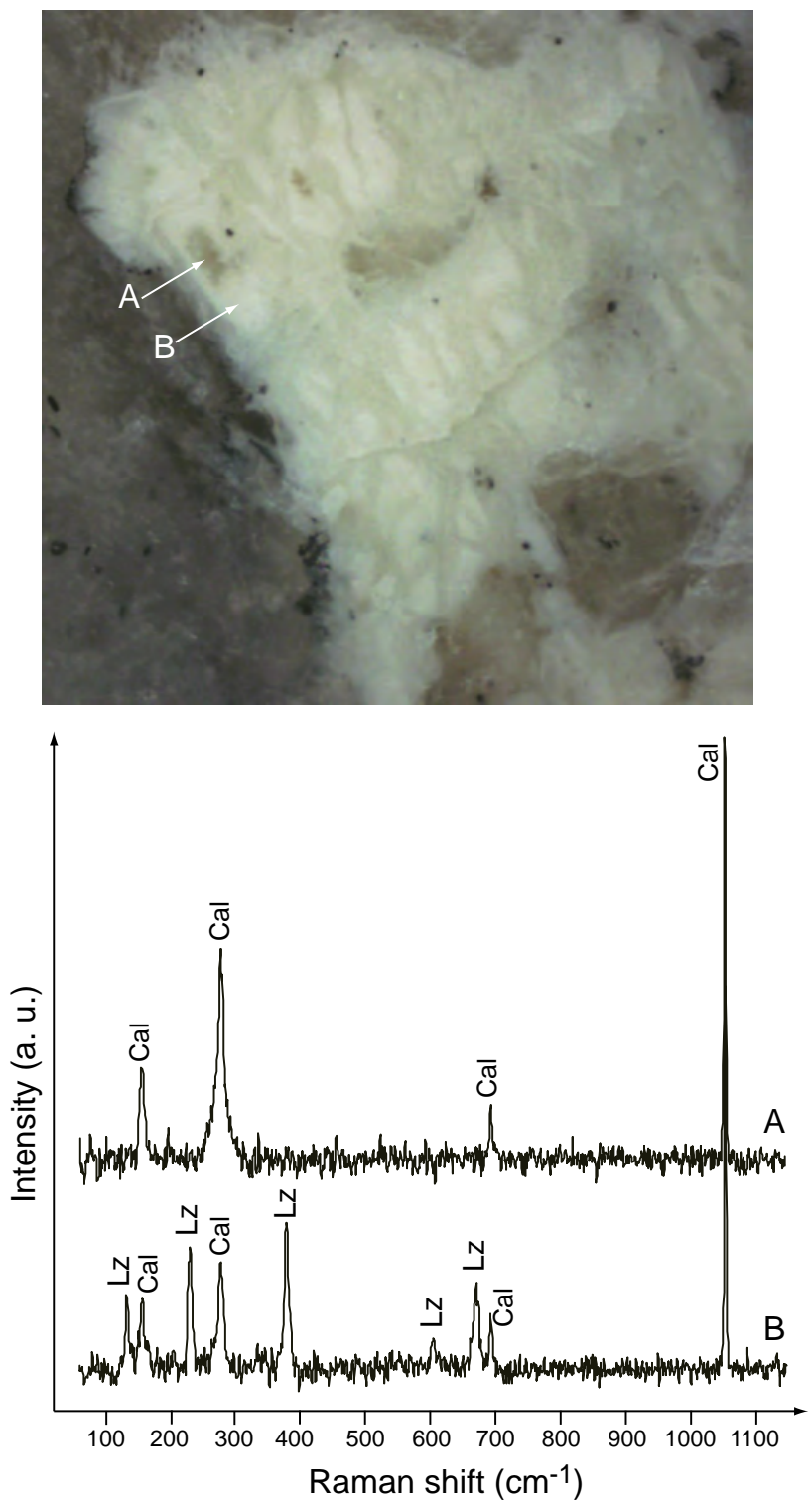

Fig. 5 Reflected light photomicrograph and two Raman spectra (A, B) of mineral constituents in the microcrystalline pseudomorphs mimicking mesh-textured olivine shape (A-11, Fig. 2). 
Although marble xenoliths essentially consist of calcite grains, they also contain mineral nodules mimicking olivine shape and mesh texture. In these pseudomorphs, Raman spectrometry indicates the presence of lizardite both in the mesh centres and rims (Fig. 5), supporting a previous presence of olivine (forsterite).

\subsubsection{Microgranite}

The orthogneiss mass is crosscut by microgranite dykes mainly consisting of Qz, Kfs and $\mathrm{Ab}$, with a total absence of micas. Granite has a medium-grained equigranular texture, in which quartz exhibits effects of intense ductile deformation.

\subsection{Deformation}

In addition to the characteristic $\mathrm{S}_{1}$ metamorphic foliation, orthogneiss also rarely exhibits evidence for post-peak mylonitic foliation (Fig. 6a). There are two boreholes in the northern flank of the SzD (Sz-N-2, and Sz-N11), which penetrated over $200 \mathrm{~m}$ into the mylonitic zone, making microstructural analysis of a continuous (mylonitic) and a subsequent discontinuous (cataclastic) deformation event possible (Schubert and Tóth 2001). Sampling along the two drillings was irregular; hence, core sections represent different depth intervals of the same shear zone. As the spatial orientation of the studied cores is unknown, they are useless for a detailed kinematic interpretation. However, they unequivocally prove the existence of a ductile shear zone at the given depth interval affecting the orthogneiss body and the change in deformation intensity and style with depth.

Based on the occurrence of the original rock-forming minerals as well as deformation effects, the rock column can be subdivided roughly into three intervals - the upper zone, the transitional zone and the bottom zone. The upper zone is only slightly altered, allowing the original mineralogical and textural features to be clearly observed, while maximal strain is reached at the deepest structural level. The vertical variations typically are: a) progressive replacement of the matrix biotite by chlorite and fine opaque grains; b) chlorite is replaced by white mica; c) average grain size decreases; d) the number of garnet porphyroclasts/pseudomorphs diminishes; e) the proportion of recrystallized quartz grains increases; f) the gneissose structure is succeeded by a mylonitic foliation (Fig. 6b, d); g) the S/C-microstructure becomes more characteristic (Fig. 6c).

The upper zone is the least deformed, it is characterized by coarser grain size and a relatively high amount of garnet porphyroclasts (Fig. 6a). Quartz alternates with mica-rich domains and forms strongly elongated lenses or ribbons, which are generally bordered by phyllosili- cate packets (Fig. 6a). Quartz grains in the lenses show undulatory extinction. Weakly developed S/C fabric can be observed at several places (Fig. 6a) and mylonitic foliation appears at micro-scale (Fig. 6a). The rocks consist dominantly of quartz, feldspars and mica. The fresh feldspar porphyroclasts often show sweeping extinction and curved deformation twins, while vast majority of feldspar grains break down to very fine-grained aggregates of quartz and white mica or are replaced by fine-grained carbonate. The phyllosilicate grains are usually white mica or chlorite and subordinately pale brown biotite ranging up to $2.5 \mathrm{~mm}$ in size. White mica frequently forms mica fishes (Fig. 6a). Chlorite flakes occur consequently together with opaque grains along their cleavage planes suggesting a biotite precursor. Porphyroclasts with pressure shadows, in which the core is composed of garnet, are common. However, in most cases the garnet core, whose diameter may range up to $3 \mathrm{~mm}$, is not preserved anymore and is replaced by a fine-grained $\mathrm{Cb} \pm \mathrm{Qz} \pm \mathrm{Bt} \pm \mathrm{Chl}$ aggregate (Fig. 6b). The pressure shadows are composed of $\mathrm{Qz} \pm \mathrm{Ms} \pm \mathrm{Chl} \pm \mathrm{Cb}$.

Rock samples of the transition zone consist essentially of medium-grained feldspar and quartz with fine-grained foliation-parallel quartz domains. Biotite is almost entirely replaced by chlorite. White mica and chlorite flakes form mica fishes with roughly equal grain size. Quartz generally occurs as recrystallized and strongly elongated lenses or ribbons. Scarce garnet grains up to $500 \mu \mathrm{m}$ in size are pseudomorphosed by $\mathrm{Chl} \pm \mathrm{Cb} \pm \mathrm{Qz} \pm \mathrm{Opq}$ phases. In places, mylonite is chaotically folded.

The rock samples that represent the deepest part of the shear zone are mainly quartzo-feldspathic mylonite. The S/C-microstructure is well-developed; the $\mathrm{C}$ foliation planes are defined by high contiguity chlorite bunches with numerous opaque mineral grains along the cleavage planes (Fig. 6c). Chlorite and white mica up to $3 \mathrm{~mm}$ in size generally form mica fishes parallel to the mylonitic foliation (Fig. 6d). Huge quartz grains (c. $10 \mathrm{~mm}$ ) are boudinaged and oriented sub-parallel to the foliation in the fine-grained matrix. The necks and fractures within the boudins consist of sparse carbonate. The grains of this carbonate are intensively twinned. Remnants of pseudomorphosed garnet porphyroclasts, common in the two upper sections of the shear zone, are missing. Microfractures filled by early up-grown quartz and late, spare carbonate are common. They usually cut the mylonitic foliation at a high angle but in several cases they crosscut only microlithons between mylonitic cleavage domains, or are oriented parallel to the foliation.

At all structural levels of the shear zone, microstructural features typical of post-mylonitic cataclasis are frequent. In some hand specimens, fresh mylonite and cohesive cataclasite are in contact along sharp boundaries. In the very fine-grained carbonate-cemented cataclasite, 


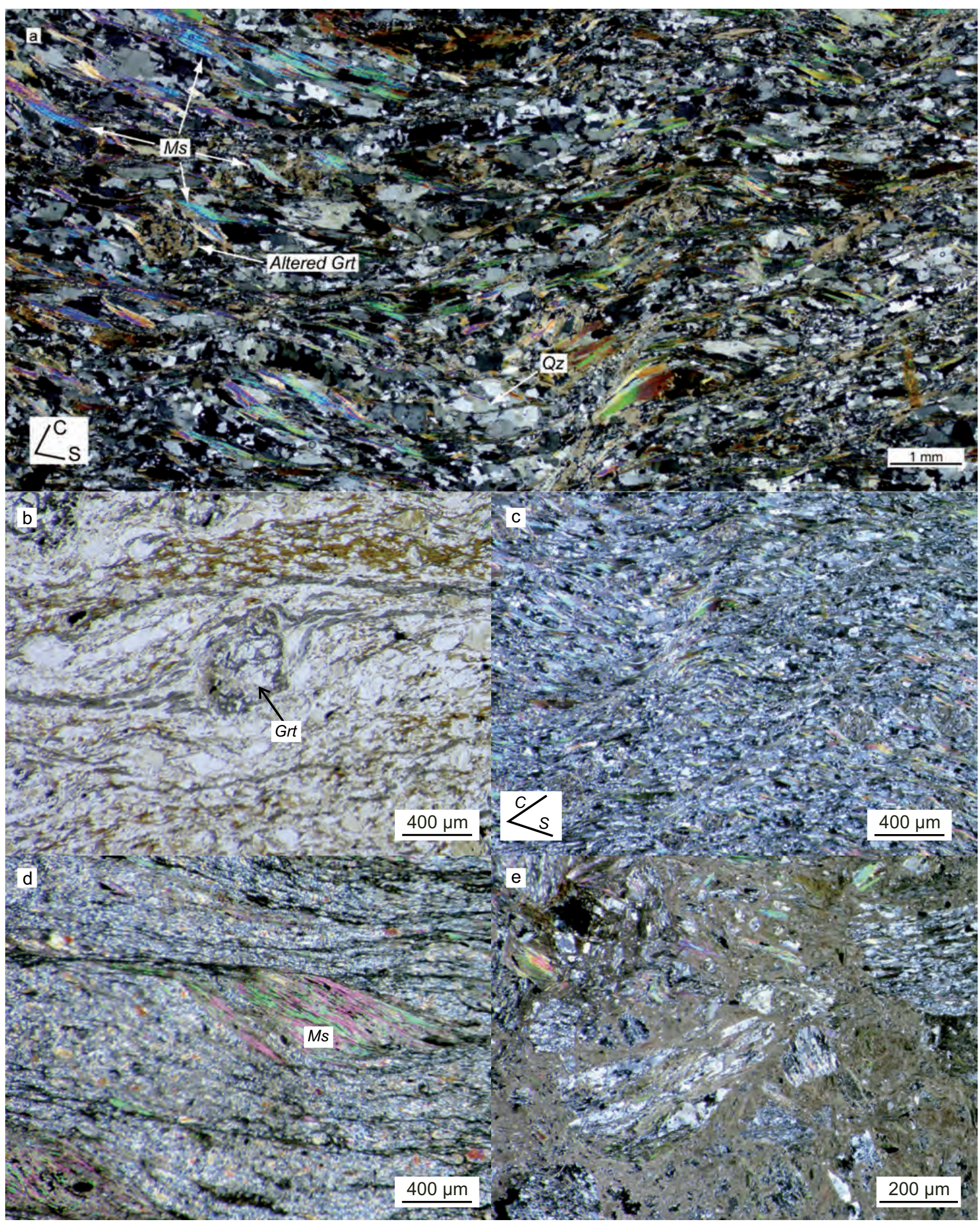

Fig. 6 Photomicrographs representing the orthogneiss mylonite. a - Typical texture of the orthogneiss mylonite in the uppermost part of the shear zone (XPL, northern slope of SzD, Fig. 1). b - Garnet $\sigma$-clast (PPL, northern slope of SzD, Fig. 1). $\mathbf{c}$ - High-strain shear bands crosscutting the main foliation contain fine-grained quartz \pm chlorite \pm carbonate infill (XPL, northern slope of SzD, Fig. 1). d - Mica fish in orthogneiss mylonite (XPL, northern slope of SzD, Fig. 1). e - Fine-grained carbonate-cemented breccia consisting of mylonitic clasts (XPL, northern slope of SzD, Fig. 1) 

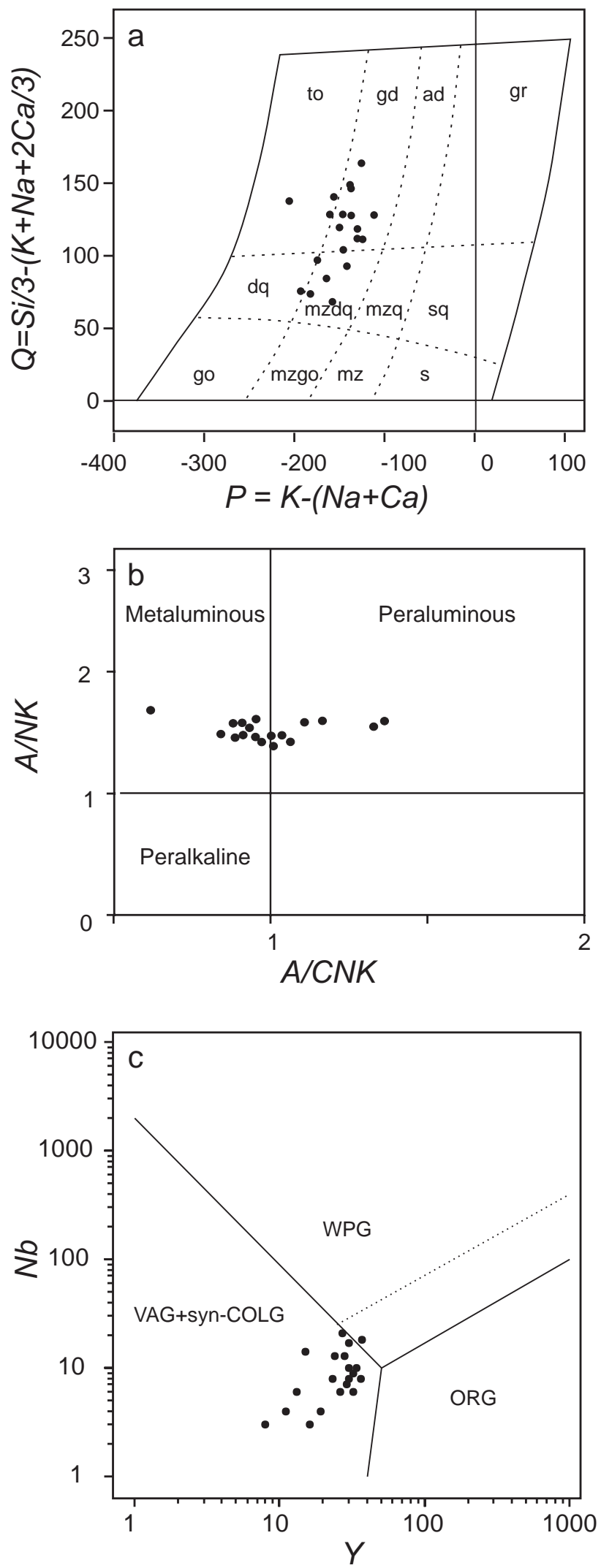

Fig. 7 Geochemical diagrams to discriminate the protolith of the orthogneiss: a - P vs. Q (Debon and Le Fort 1983). b-A/CNK vs. A/NK (Maniar and Piccoli 1989). c - Y vs. Nb (Pearce et al. 1984). boudinaged quartz grains with a strong undulose extinction or mylonite fragments define the clasts (Fig. 6e). Detailed analysis of this late brittle event is out of the scope of the present paper.

\subsection{Whole-rock geochemistry}

Although the orthogneiss samples are slightly heterogeneous in composition (Tab. 2) due to the various amounts of xenocrysts, they all define a reasonably well-defined cloud in each discriminant diagram (Fig. 7). The protolith of the orthogneiss may have been quartz monzodiorite to granodiorite (Debon and Le Fort 1983; Fig. 7a) with metaluminous to peraluminous character (Fig. 7b). Diagrams of Pearce et al. (1984) and Maniar and Piccoli (1989) imply a magmatic-arc related granitic protolith (e.g., Fig. 7c).

The geochemistry of the amphibolite xenoliths has been discussed in detail by Tóth (2012). All of the studied specimens represent MOR basalts significantly depleted in LREE and other incompatible elements.

\subsection{Mineral chemistry}

\subsubsection{Orthogneiss}

In the polygonal texture of the orthogneiss, both K-feldspar and plagioclase are common constituents. K-feldspar is almost pure in composition ( $\mathrm{Ab}<6 \mathrm{~mol}$ \%) (Tab. 3), with a slight increase of the Or component towards the rim $\left(\mathrm{Or}_{94} \rightarrow \mathrm{Or}_{98}\right)$. In places, the Kfs grains enclose myrmekitic plagioclase inclusions $\left(\mathrm{An}_{20}\right)$. Matrix plagioclase is zoned with cores of $\mathrm{An}_{35-40}$, while towards the rim the albite component increases $\left(\mathrm{An}_{20-22}\right)$. Plagioclase inclusions in amphibole xenocrysts are of $\sim \mathrm{An}_{20}$.

For matrix biotite, $\mathrm{Mg \#} \sim 0.45-0.65$ (where $\mathrm{Mg \#}=$ $100 \times \mathrm{Mg} /(\mathrm{Mg}+\mathrm{Fe}))$ and $\mathrm{Ti} \sim 0.15-0.25$ apfu (atom per formula unit) are typical, the proportion of the Tschermak molecule is small ( $\mathrm{Si} \sim 2.7-2.9 \mathrm{apfu}), \mathrm{Al}^{\text {tot }}$ is around 1.3-1.6 apfu, and $\mathrm{Na}$ is negligible. In some large biotite flakes the core has $\mathrm{Ti}>0.4$ apfu. White mica is almost pure muscovite with $\mathrm{Si} \sim 3.2$ apfu and $\mathrm{Na} /(\mathrm{Na}+\mathrm{K}) \sim$ 0.05 ; in the celadonite member $\mathrm{Mg \#} \sim 0.50$.

Clinopyroxene xenocrysts are augites with slightly varied compositions $\left(\mathrm{Wo}_{33-47} \mathrm{En}_{27-35} \mathrm{Fs}_{22-30} \mathrm{Ac}_{0-4}\right)$. The Ti content is generally low $\left(\mathrm{TiO}_{2} \sim 0.02-0.12\right.$ wt. \%), $\mathrm{MnO}$ is $0.5-0.8$ wt. $\%, \mathrm{Na}_{2} \mathrm{O}$ is $0.6-0.9$ wt. $\%$, and $\mathrm{Cr}$ is negligible. The most common xenocryst type of the orthogneiss is amphibole, which surrounds $\mathrm{Cpx}$ grains in places. In both textural situations, amphibole touches matrix quartz and feldspar and its composition is similar in all studied samples. The core is close to hastingsite and tschermakite (Leake et al. 1997) with $\mathrm{Si} \sim 6.0$ apfu; 
Orthogneisses of the Tisza Megaunit

generally $\mathrm{Al}^{\mathrm{VI}} \sim 0.2-0.5 \mathrm{apfu}$, $\mathrm{Mg \#} \sim 0.4-0.5, \mathrm{Na}^{\mathrm{M} 4} \sim 0.2 \mathrm{apfu}$, and $(\mathrm{Na}+\mathrm{K})^{\mathrm{A}}<0.4$ apfu. Towards the rim $\mathrm{Si}$ increases, while $\mathrm{Al}^{\text {tot }}$ and $\mathrm{Ti}$ decrease. The rim composition is $\mathrm{Mg}$-hornblende due to the diminishing tschermakite and edenite components (Si 6.6-7.0 apfu).

Garnet xenocrysts of different specimens exhibit a rather wide spectrum of compositions and zoning patterns; in fact no typical composition can be mentioned. A usual example is a normally zoned with increasing $\mathrm{Fe}$ and $\mathrm{Mg}$ and decreasing $\mathrm{Mn}$ rimwards $\left(\mathrm{Alm}_{55}\right.$ $\mathrm{Sps}_{23} \mathrm{Grs}_{18} \mathrm{Prp}_{4} \rightarrow \mathrm{Alm}_{75} \mathrm{Sps}_{0}$ $\left.\mathrm{Grs}_{15} \operatorname{Prp}_{10}\right)$. Other garnet grains, in general those of amphibole-bearing samples, are much lower in almandine and higher in grossular $\left(\right.$ Alm $_{47-49}$ Sps $_{15-17}$ Grs $_{30-32} \operatorname{Prp}_{4-5}$ ). Occasionally (Fig. 3f), garnet is almost entirely replaced by chlorite (clinochlore with $\mathrm{Al}^{\text {tot }}>5.0$ apfu, $\mathrm{Al}^{\mathrm{IV}} \sim 2.5$ apfu, $\left.\mathrm{Mg \#} \sim 0.5\right)$; the pseudomorph is surrounded by biotite $(\mathrm{Mg \#} \sim 0.5, \mathrm{Ti}<0.2$ apfu, $\mathrm{Si} \sim 2.8-3.2$ apfu).

Epidote grains are unzoned, $\mathrm{Al} /$ $\left(\mathrm{Al}+\mathrm{Fe}^{3+}\right) \sim 0.8$; matrix ilmenite is low in pyrophanite $(\sim 3$ mol. \%).

\subsubsection{Mafic xenoliths}

Amphibole of the studied garnetiferous amphibolite xenoliths is typically hastingsite $\left(\mathrm{Si}<6.2\right.$ apfu, $\mathrm{Al}^{\mathrm{VI}} \sim 0.4$ apfu); the rim is more edenitic $\left(\mathrm{Si} \sim 6.5-6.8 \mathrm{apfu}\right.$; $\mathrm{Al}^{\mathrm{VI}} \sim$ 0.5-0.7 apfu; $\left.\mathrm{Na}^{\mathrm{A}} \sim 0.5-0.7 \mathrm{apfu}\right)$. Garnet is not zoned; its composition is stable around $\mathrm{Alm}_{51-57} \mathrm{Sps}_{0-3} \mathrm{Grs}_{30-35} \operatorname{Prp}_{8-12}$. For matrix plagioclase composition, $\sim \mathrm{An}_{40}$ is typical.

Two eclogite specimens were studied in detail (Tóth 1995, 1997). Clinopyroxene of the original composition was not observed; recrystallized amphiboles contain tiny inclusions of $\mathrm{Di}_{70-75} \mathrm{Hd}_{25-30} \mathrm{Jd}_{0-3}$ clinopyroxene. The compositions of the garnet grains in the two samples are only slightly different. In the more symplectitic sample, garnet fragments are of $\mathrm{Alm}_{46} \mathrm{Sps}_{1} \mathrm{Grs}_{23} \operatorname{Prp}_{30}$, while in another one, garnet grains are $\mathrm{Alm}_{40-43} \mathrm{Sps}_{1-2} \mathrm{Grs}_{20-25} \operatorname{Prp}_{35-38}$ without any significant zoning. In both samples phengite flakes both in the rock matrix and as inclusions of the large amphibole crystals are of similar composition: $\mathrm{Si} \sim 3.3-3.4$ apfu $\left(\mathrm{Si}_{\max }=3.5\right)$ and $\mathrm{Mg \#} \sim 0.6-0.7$ are
Table 3a Representative mineral compositions of the host orthogneisses and typical xenoliths - feldspars, clinopyroxene, cordierite and spinel (wt. \% and apfu; end members in mol. \%)

\begin{tabular}{|c|c|c|c|c|c|c|}
\hline \multirow[b]{2}{*}{ Mineral } & \multicolumn{4}{|c|}{ Orthogneiss matrix } & \multicolumn{2}{|c|}{ Granulite xenolith } \\
\hline & $\begin{array}{l}\text { Kfs } \\
\text { core }\end{array}$ & $\begin{array}{l}\text { Kfs } \\
\text { rim }\end{array}$ & P1 & Cpx & Crd & Spl \\
\hline $\mathrm{SiO}_{2}$ & 63.89 & 64.41 & 61.64 & 52.41 & 49.53 & 0.86 \\
\hline $\mathrm{TiO}_{2}$ & 0.00 & 0.00 & 0.02 & 0.06 & 0.01 & 0.04 \\
\hline $\mathrm{Al}_{2} \mathrm{O}_{3}$ & 18.32 & 18.24 & 23.25 & 1.38 & 32.53 & 58.32 \\
\hline $\mathrm{FeO}$ & 0.05 & 0.36 & 0.16 & 12.71 & 12.37 & 35.40 \\
\hline $\mathrm{MnO}$ & 0.00 & 0.02 & 0.04 & 0.61 & 0.04 & 0.12 \\
\hline $\mathrm{MgO}$ & 0.03 & 0.00 & 0.03 & 9.97 & 3.09 & 5.06 \\
\hline $\mathrm{CaO}$ & 0.03 & 0.02 & 7.05 & 20.66 & 0.03 & 0.09 \\
\hline $\mathrm{Na}_{2} \mathrm{O}$ & 0.60 & 0.27 & 6.90 & 0.83 & 0.19 & 0.22 \\
\hline $\mathrm{K}_{2} \mathrm{O}$ & 15.68 & 16.99 & 0.11 & 0.00 & 0.11 & 0.10 \\
\hline Total & 98.59 & 100.31 & 99.20 & 98.63 & 98.12 & 100.21 \\
\hline $\mathrm{O}$ & 8 & 8 & 8 & 6 & 18 & 4 \\
\hline $\mathrm{Si}$ & 2.99 & 2.99 & 2.76 & 2.02 & 5.18 & 0.02 \\
\hline $\mathrm{Ti}$ & 0.00 & 0.00 & 0.00 & 0.00 & 0.00 & 0.00 \\
\hline $\mathrm{Al}$ & 1.01 & 1.00 & 1.23 & 0.06 & 4,02 & 1.93 \\
\hline $\mathrm{Fe}$ & 0.00 & 0.01 & 0.01 & 0.41 & 1,08 & 0.83 \\
\hline $\mathrm{Mn}$ & 0.00 & 0.00 & 0.00 & 0.02 & 0.00 & 0.00 \\
\hline $\mathrm{Mg}$ & 0.00 & 0.00 & 0.00 & 0.57 & 0.48 & 0.21 \\
\hline $\mathrm{Ca}$ & 0.00 & 0.00 & 0.34 & 0.85 & 0.00 & 0.00 \\
\hline $\mathrm{Na}$ & 0.05 & 0.02 & 0.60 & 0.06 & 0.04 & 0.01 \\
\hline $\mathrm{K}$ & 0.94 & 1.00 & 0.01 & 0.00 & 0.01 & 0.00 \\
\hline Total & 5.00 & 5.03 & 4.93 & 4.00 & 10.83 & 3.02 \\
\hline An & 0.00 & 0.00 & 0.36 & & & \\
\hline $\mathrm{Ab}$ & 0.06 & 0.02 & 0.64 & & & \\
\hline Or & 0.94 & 0.98 & 0.00 & & & \\
\hline Wo & & & & 0.47 & & \\
\hline En & & & & 0.31 & & \\
\hline Fs & & & & 0.22 & & \\
\hline
\end{tabular}

typical, with negligible amounts of $\mathrm{Na}$ and $\mathrm{Ti}$. Kyanite contains less than 0.01 apfu of Fe; in the clinozoisite $\mathrm{Fe} /(\mathrm{Fe}+\mathrm{Al})$ changes between 0.03 and 0.13 . The white mica coronas around kyanite grains are margarite surrounded by an external rim of muscovite ( $\mathrm{Si}<3.0 \mathrm{apfu})$. In places the original phengite is rimmed by margarite, as well. Titanite is pure; its Al content is negligible. In the less symplectitic sample, all altered eclogite mineral relicts (garnet partially replaced by feldspar, kyanite, rutile and phengite with white mica corona) occur in the matrix as well as form inclusions in the large amphibole grains (Fig. 4d). These amphibole grains are barroisitic with significantly increasing $\mathrm{Al}^{\mathrm{IV}}(0.7 \rightarrow 1.3 \mathrm{apfu})$ and decreasing $\mathrm{Al}^{\mathrm{VI}}(0.6 \rightarrow 0.35 \mathrm{apfu})$ and $\mathrm{Na}^{\mathrm{M} 4}(0.35 \rightarrow 0.15$ apfu) towards the rims. The composition of the amphibole crystals is nevertheless significantly different in the more symplectitic sample. Here the symplectite-forming amphibole is Mg-hornblende, while the larger grains are zoned with tschermakitic cores and rimward decreasing $\mathrm{Al}\left(\mathrm{Al}^{\mathrm{IV}} 1.9 \rightarrow 0.8 \mathrm{apfu} ; \mathrm{Al}^{\mathrm{VI}} 0.9 \rightarrow 0.1 \mathrm{apfu}\right)$ and alkalis $\left((\mathrm{Na}+\mathrm{K})^{\mathrm{A}} 0.4 \rightarrow 0.0 \mathrm{apfu}\right)$. Symplectitic plagioclase is albite $\left(A n_{1-7}\right)$, while the large, recrystallized grains are more calcic at the $\operatorname{rim}\left(\mathrm{An}_{37-47}\right)$ 


\subsubsection{Felsic granulite}

Garnet of the granulite sample is essentially unzoned; at the rim there is a thin zone with increasing Fe and Mn, while decreasing $\mathrm{Mg}$ is detectable. The homogeneous grains are rather low in Grs component $\left(\mathrm{Alm}_{63-69} \mathrm{Sps}_{1-2} \mathrm{Grs}_{5-8}\right.$ $\operatorname{Prp}_{21-26}$ ). The matrix biotite core is of $\mathrm{Mg} \# \sim 0.5$ with $\mathrm{Ti}$ $\sim 0.40-0.47$ apfu, $\mathrm{Si} \sim 2.7-2.8 \mathrm{apfu}, \mathrm{Al}^{\text {tot }} \sim 1.4-1.6 \mathrm{apfu}$, and $\mathrm{Na} \sim 0.1-0.2 \mathrm{apfu}$. The rim of the large biotite laths as well as the composition of the tiny, homogeneous biotites is slightly different, with $\mathrm{Ti} \sim 0.25-0.30$ apfu and $\mathrm{Mg} \# \sim 0.5$. Phengite ( $\mathrm{Si} \sim 3.20-3.45 \mathrm{apfu}$ ) primarily appears as inclusions in garnet grains. Cordierite is high in $\mathrm{Fe} ; \mathrm{Mg} /(\mathrm{Mg}+\mathrm{Fe}+\mathrm{Mn}) \sim 0.33, \mathrm{Mn} \sim 0.03 \mathrm{apfu}$, and $\mathrm{Na} \sim 0.04$ apfu are typical. The spinel coronas around kyanite are hercynitic with $\mathrm{Fe} /(\mathrm{Fe}+\mathrm{Mg}) \sim 0.8 ; \mathrm{Mn}, \mathrm{Cr}$, and $\mathrm{Zn}$ are subordinate. Feldspar appears in three textural positions. Both plagioclase (the typical composition is $\left.\mathrm{An}_{35-42} \mathrm{Ab}_{56-64} \mathrm{Or}_{1-8}\right)$ and $\mathrm{K}$-feldspar form inclusions in garnet. Matrix plagioclase is less calcic $\left(\mathrm{An}_{18-20} \mathrm{Ab}_{78-80} \mathrm{Or}_{2}\right)$ than that which appears in the coronas around garnet $\left(\mathrm{An}_{33-40} \mathrm{Ab}_{56-58} \mathrm{Or}_{3-8}\right)$. The few amphibole grains of the granulite samples are hastingsite with $\mathrm{Si} \sim 6.3 \mathrm{apfu}, \mathrm{Al}^{\text {tot }}$ $\sim 1.9$ apfu, $\mathrm{Mg} \# \sim 0.35, \mathrm{Na}^{\mathrm{M} 4} \sim 0.25 \mathrm{apfu}$, and $(\mathrm{Na}+\mathrm{K})^{\mathrm{A}}$ $\sim 0.5-0.6$ apfu.

\subsection{Thermobarometry}

\subsubsection{Orthogneiss}

Thermobarometric modelling of the peak metamorphic assemblage of the orthogneiss is rather problematic because the xenolith-free samples have a very simple mineralogy: quartz, K-feldspar, plagioclase, biotite and muscovite. For muscovite-bearing samples, diagnostic is the absence of Al-rich minerals as garnet, kyanite or sillimanite. Nevertheless, the presence of different xenocrysts may result in modification of the original chemical composition defining independent domains with local mineral assemblages. Clinopyroxene grains, for example, are always rimmed by amphibole, while orthogneiss with amphibole xenocrysts usually contains other $\mathrm{Ca}$-silicates (e.g. titanite, epidote) as well.

Based on nine different samples (Tab. 2), garnet would be present above $580^{\circ} \mathrm{C}$, and sillimanite at even higher $T$. The total absence of these phases implies peak metamorphic temperature lower than $\sim 610^{\circ} \mathrm{C}$ (Fig. 8).

Biotite flakes that define schistosity are generally low in $\mathrm{Ti}$, while $\mathrm{Mg} \# \sim 0.5$ is typical. Using the thermometer of Henry et al. (2005) this composition suggests $T=$ $550-620^{\circ} \mathrm{C}$. High-Ti biotite cores suggest $T>700^{\circ} \mathrm{C}$ and probably represent igneous relicts (Fig. 9). Although numerous orthogneiss samples contain garnet xenocrysts surrounded by biotite, there is no textural evidence that garnet and biotite have ever been in equilibrium. Instead, the texture suggests that chloritization of garnet was followed by biotite formation due to the reaction of chlorite and matrix muscovite (Fig. 3f). Thus even if a Grt-Bt pair is absent, equilibrium pressure can be estimated based on the Chl-Ms-Bt paragenesis (Bucher 1987); assuming $T \sim 550-620^{\circ} \mathrm{C}, P$ is c. 4.2 kbar. Rims of matrix alkali and plagioclase feldspar grains in contact suggest equilibrium conditions of $T \sim 600{ }^{\circ} \mathrm{C}$ and $P<5$ kbar. Results of the ther-
Grt, Bt, PI, Crd, Mt, Kfs, Qz

\section{2} 400

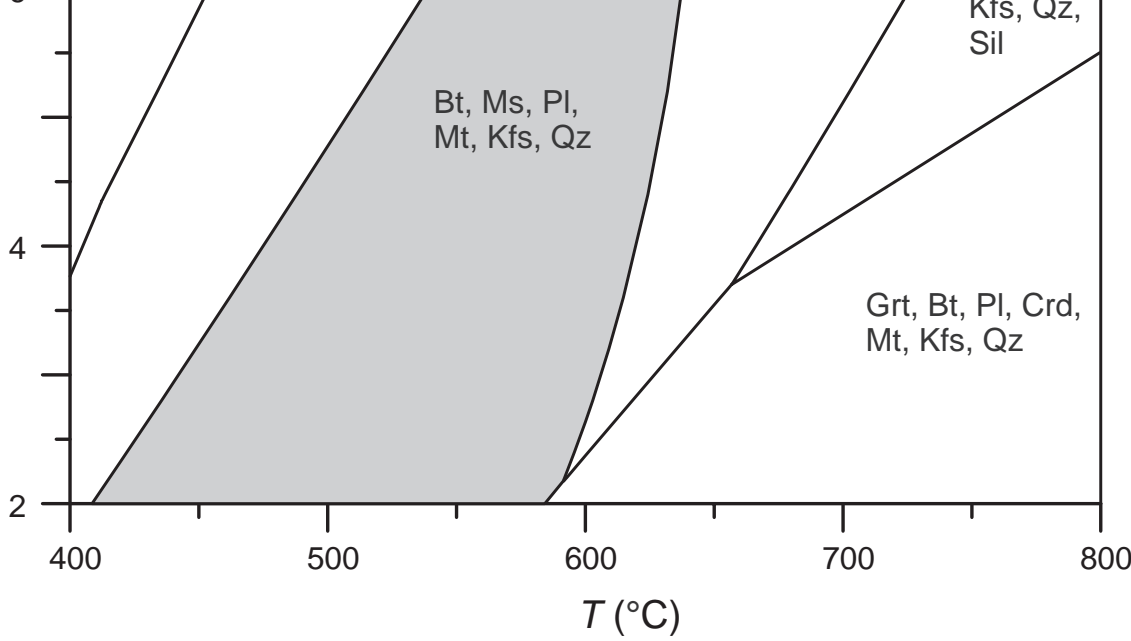

Fig. 8 Typical Domino model for the orthogneiss in the CKNFMASH system. Shaded area represents the characteristic mineral paragenesis. For modelling a real bulk composition was used (OG5, Tab. 2). 
Orthogneisses of the Tisza Megaunit

mobarometric calculations are summarized in Fig. 10.

\subsubsection{Xenocrysts}

While garnet was not stable in the orthogneiss, the uniform composition of amphibole xenocryst rims (Mg-hornblende) in different samples suggests recrystallization under identical conditions. While cores define slightly different $P$ and $T$ on the diagram of Gerya et al. (1997) (Fig. 11), each crystal exhibits a clear cooling trend towards the rim, approximately in the range of $T \sim 660-680{ }^{\circ} \mathrm{C} \rightarrow 580-620^{\circ} \mathrm{C}$ and $P \sim 3.0-4.5 \mathrm{kbar} \rightarrow 2.0-3.5$ kbar (Fig. 11).

The negligible amount of jadeite component as well as the very low $\mathrm{Cr}$-content in the Cpx xenocrysts suggests lowpressure formation. Using the enstatite-in-Cpx thermometer of Nimis and Taylor (2000) and assuming 2-5 kbar pressure yields $\sim 810-830^{\circ} \mathrm{C}$ (Fig. 10a). The composition of the amphibole overgrowths around these $\mathrm{Cpx}$ crystals fits well with the cooling trend defined by amphibole xenocrysts in Figs 10a and 11.
Table 3b Representative mineral compositions of the host orthogneisses and typical xenoliths - amphibole (SumCa $=15$ method, Spear and Kimball 1984) (wt. \% and apfu; end members in mol. \%)

\begin{tabular}{|c|c|c|c|c|c|c|c|}
\hline & \multicolumn{2}{|c|}{ Orthogneiss matrix } & \multicolumn{4}{|c|}{ Eclogite xenolith } & \multirow{2}{*}{$\frac{\text { Amphibolite xenolith }}{\text { Amp core }}$} \\
\hline & Amp core & Amp rim & Amp core & Amp rim & Amp recr & Amp sym & \\
\hline $\mathrm{SiO}_{2}$ & 38.55 & 42.49 & 52.00 & 51.98 & 40.00 & 49.70 & 41.19 \\
\hline $\mathrm{TiO}_{2}$ & 1.18 & 0.92 & 0.10 & 0.12 & 1.43 & 0.25 & 1.18 \\
\hline $\mathrm{Al}_{2} \mathrm{O}_{3}$ & 12.13 & 8.77 & 7.44 & 8.68 & 15.10 & 5.31 & 12.65 \\
\hline $\mathrm{FeO}$ & 23.83 & 23.14 & 6.51 & 6.40 & 14.51 & 13.58 & 18.84 \\
\hline $\mathrm{MnO}$ & 0.84 & 1.05 & 0.15 & 0.01 & 0.17 & 0.26 & 0.25 \\
\hline $\mathrm{MgO}$ & 5.59 & 6.77 & 18.78 & 19.01 & 9.48 & 13.88 & 9.24 \\
\hline $\mathrm{CaO}$ & 10.87 & 11.25 & 10.49 & 8.81 & 10.57 & 10.90 & 11.57 \\
\hline $\mathrm{Na}_{2} \mathrm{O}$ & 1.58 & 1.12 & 1.54 & 2.41 & 1.58 & 0.47 & 1.93 \\
\hline $\mathrm{K}_{2} \mathrm{O}$ & 1.80 & 1.15 & 0.17 & 0.26 & 0.77 & 0.14 & 0.58 \\
\hline Total & 96.36 & 96.66 & 97.18 & 97.68 & 93.59 & 94.48 & 97.44 \\
\hline $\mathrm{Si}$ & 6.13 & 6.65 & 7.31 & 7.24 & 6.19 & 7.44 & 6.23 \\
\hline $\mathrm{Ti}$ & 0.14 & 0.11 & 0.01 & 0.01 & 0.17 & 0.03 & 0.13 \\
\hline $\mathrm{Al}$ & 2.27 & 1.62 & 1.23 & 1.42 & 2.75 & 0.94 & 2.26 \\
\hline $\mathrm{Fe}(\mathrm{III})$ & 0.34 & 0.31 & 0.00 & 0.00 & 0.00 & 0.00 & 0.33 \\
\hline $\mathrm{Fe}(\mathrm{II})$ & 2.83 & 2.72 & 0.76 & 0.75 & 1.88 & 1.70 & 2.05 \\
\hline $\mathrm{Mn}$ & 0.11 & 0.14 & 0.02 & 0.00 & 0.02 & 0.03 & 0.03 \\
\hline $\mathrm{Mg}$ & 1.32 & 1.58 & 3.93 & 3.95 & 2.19 & 3.10 & 2.08 \\
\hline $\mathrm{Ca}$ & 1.85 & 1.89 & 1.58 & 1.31 & 1.75 & 1.75 & 1.88 \\
\hline $\mathrm{Na}$ & 0.49 & 0.34 & 0.42 & 0.65 & 0.47 & 0.14 & 0.57 \\
\hline $\mathrm{K}$ & 0.37 & 0.23 & 0.03 & 0.05 & 0.15 & 0.03 & 0.11 \\
\hline Total & 15.85 & 15.57 & 15.29 & 15.38 & 15.58 & 15.15 & 15.68 \\
\hline $\mathrm{Si}$ & 6.13 & 6.65 & 7.31 & 7.24 & 6.19 & 7.44 & 6.23 \\
\hline $\mathrm{Al}$ (IV) & 1.87 & 1.35 & 0.69 & 0.76 & 1.81 & 0.56 & 0.77 \\
\hline $\mathrm{Al}(\mathrm{VI})$ & 0.40 & 0.26 & 0.54 & 0.67 & 0.95 & 0.38 & 0.49 \\
\hline $\mathrm{Ti}$ & 0.14 & 0.11 & 0.01 & 0.01 & 0.17 & 0.03 & 0.13 \\
\hline $\mathrm{Fe}$ (III) & 0.34 & 0.31 & 0.00 & 0.00 & 0.00 & 0.00 & 0.33 \\
\hline $\mathrm{Fe}(\mathrm{II})$ & 2.83 & 2.72 & 0.76 & 0.75 & 1.88 & 1.70 & 2.05 \\
\hline $\mathrm{Mn}$ & 0.11 & 0.14 & 0.02 & 0.00 & 0.02 & 0.03 & 0.03 \\
\hline $\mathrm{Mg}$ & 1.32 & 1.58 & 3.93 & 3.95 & 2.19 & 3.10 & 2.08 \\
\hline $\mathrm{Ca}$ & 1.85 & 1.89 & 1.58 & 1.31 & 1.75 & 1.75 & 1.88 \\
\hline $\mathrm{Na}$ & 0.49 & 0.34 & 0.42 & 0.65 & 0.47 & 0.14 & 0.57 \\
\hline $\mathrm{K}$ & 0.37 & 0.23 & 0.03 & 0.05 & 0.15 & 0.03 & 0.11 \\
\hline
\end{tabular}

sym: symplectitic grain, recr: recrystallized grain

\subsubsection{Mafic xenoliths}

The Grt-Amp-Pl paragenesis of the studied garnetiferous amphibolite xenoliths suggests a temperature of $\sim 620^{\circ} \mathrm{C}$ according to the thermometer of Graham and Powell (1984), while pressure is estimated at $7.5-8.2$ kbar using the method of Kohn and Spear (1990). Nevertheless, increasing $\mathrm{Al}^{\mathrm{IV}}$ and decreasing $\mathrm{Al}^{\mathrm{VI}}$ towards the rim of the amphibole clearly indicate a low-pressure heating up to $\sim 680^{\circ} \mathrm{C}$ and $3 \mathrm{kbar}$ (Gerya et al. 1997) (Fig. 10b).

Even if the original HP paragenesis has only partially survived metamorphic overprint, the peak conditions of the eclogite samples can be modelled using the relict phases. Eclogitic Cpx has not been observed. Based on the traditional classification of Coleman et al. (1965), the average pyrope content of garnets suggests B-type eclogites. This is in good agreement with the results of the Grt-Ph Fe-Mg thermometry (Krogh and Råheim 1978;
Green and Hellman 1982); core compositions consequently give a temperature of $800-820^{\circ} \mathrm{C}$, while the pressure is $15 \mathrm{kbar}$ using the Si-in-phengite barometer of Massonne and Schreyer (1987).

Retrogression of the HP paragenesis can be followed by modelling the formation of plagioclase in the $\mathrm{Grt}+\mathrm{Rt}+\mathrm{Ky}+\mathrm{Ttn}+\mathrm{Pl}+\mathrm{Qz}\left(\mathrm{SiO}_{2}-\mathrm{Al}_{2} \mathrm{O}_{3}-\mathrm{FeO}-\mathrm{TiO}_{2}-\mathrm{CaO}\right)$ system. Similarly, to understand the white mica corona around kyanite, the $\mathrm{Ky}+\mathrm{Czo}+\mathrm{Mrg}+\mathrm{Qz}\left(\mathrm{SiO}_{2}-\mathrm{Al}_{2} \mathrm{O}_{3}-\right.$ $\mathrm{CaO}-\mathrm{H}_{2} \mathrm{O}$ ) system should be exploited. In the first chemical subsystem the independent reactions are as follows (1-4): grossular +2 kyanite + quartz $=3$ anorthite anorthite + rutile $=$ titanite + kyanite

grossular +3 rutile + quartz $=3$ titanite + kyanite grossular +2 rutile + quartz $=2$ titanite + anorthite

A margarite corona may form due to the reaction: 5 kyanite +2 clinozoisite $+3 \mathrm{H}_{2} \mathrm{O}=4$ margarite + 3 quartz 


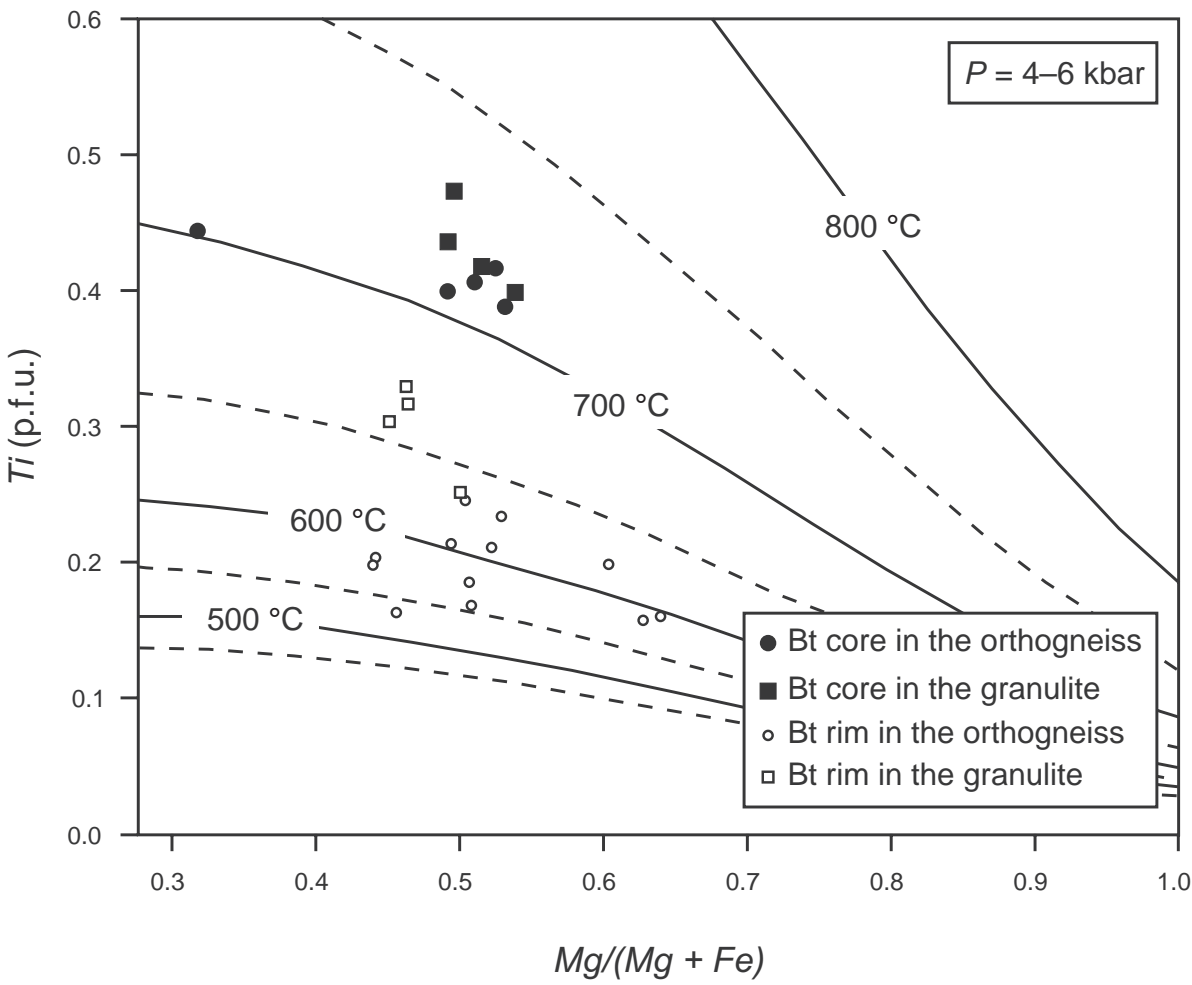

Fig. 9 Composition of biotite grains of different textural positions in the orthogneiss and granulite xenolith on the diagram of Henry et al. (2005). For details see text.
Using the measured mineral compositions, the equilibrium conditions of the above reactions were studied with TWQ software (Berman 1991). The intersection of reactions (1)-(4) indicates the equilibrium conditions of the paragenesis; that is, any garnet-plagioclase pair defines a $P_{0}-T_{0}$ point along the retrograde pathway of the eclogite. Calculation with the INTERSX subprogram of the TWQ software results in $T \sim 680-700^{\circ} \mathrm{C}, P \sim 12.8-13.4 \mathrm{kbar}$ and $T \sim 500-520^{\circ} \mathrm{C}, P \sim 8.0-8.9 \mathrm{kbar}$ in four independent cases (Fig. 12a).

The $P-T$ conditions of reaction (5) are rather uncertain, because $\mathrm{H}_{2} \mathrm{O}$ activity is hard to estimate. Nevertheless, the presence of unaltered HP minerals in the rock samples implies a relatively low water activity. That is why the reaction has been modelled for two cases, $a_{\text {н2О }}=0.3$ and $a_{\mathrm{H} 2 \mathrm{O}}=0.5$, respectively. Both models suggest that the formation of the margarite corona around kyanite reflects a further temperature drop. This result is also confirmed by the very low phengite content in the muscovite of the outermost corona. As the large amphibole porphyroblasts contain the eclogite facies' mineral inclusions together with their $L T$ alteration corona, amphibole formation had to follow retrogression. Moreover, chemical zoning of the amphibole (decreasing $\mathrm{Si}$ and increasing $\mathrm{Na}^{\mathrm{A}}$ towards the rim) clearly indicates growth due to heating. According to the single amphibole approach of Gerya et al. (1997), the conditions of the amphibolite-facies overprint are around $T_{\max } \sim 600^{\circ} \mathrm{C}$ and $P_{\text {Tmax }} \sim 2.5$ kbar (Fig. 11).

Although the symplectitic eclogite sample contains garnet and phengite of similar composition and so suggests identical peak $P-T$ conditions $\left(\sim 800^{\circ} \mathrm{C}\right.$, $\sim 15$ kbar) using Grt-Ph Fe-Mg thermometry (Krogh and Råheim 1978; Green and Hellman 1982) and Si-in-phengite barometer of Massonne and Schreyer (1987), the evolution suggested by amphiboles is different from that discussed for the previous eclogite xenolith type. While the large amphibole porphyroblasts are tschermakitic, symplectite is formed by Mg-hornblende (Si: $6.24 \rightarrow 7.00$; $\mathrm{Al}^{\text {tot: }} 2.50 \rightarrow 1.00$ ). A similar duality is typical of plagioclase; in the symplectite, feldspar it is albite $\left(\mathrm{An}_{1-7}\right)$, while large grains are more anorthitic $\left(\sim \mathrm{An}_{45}\right)$. The formation of large amphiboles took place at $\sim 680^{\circ} \mathrm{C}$ and $\sim 4.5 \mathrm{kbar}$ (using methods of Plyusnina 1982; Gerya et al. 1997), while symplectite formed at $\sim 600^{\circ} \mathrm{C}$ and $<3.0 \mathrm{kbar}$. The $P-T$ evolution of both eclogite varieties is summarized in Fig. 10c.

\subsubsection{Felsic granulite}

The evidence for the earliest event of the granulite xenolith has been preserved by inclusions in garnet. Phengite, together with garnet core, results in $T \sim$ $820-850^{\circ} \mathrm{C}$ (Green and Hellman 1982) at $\sim 13$ kbar using the Si-content of these phengite inclusions. The high Ti-content of matrix biotite cores at $\mathrm{Mg} \# \sim 0.5$ results in a formation temperature of $\sim 750^{\circ} \mathrm{C}$ according to Henry et al. (2005; Fig. 9). Keeping in mind that the stable Al-silicate phase is kyanite, it suggests a pressure of $P>9$ kbar. A similar pressure (c. 9.0-9.5 kbar) 
can be computed with the GASP barometer using plagioclase $\left(\mathrm{An}_{40}\right)$ inclusions in the garnet. Different Grt-Bt thermometers using mineral core compositions give mutually comparable results (see Ganguly and Saxena 1984: $780^{\circ} \mathrm{C}$; Dasgupta et al. 1991: $770^{\circ} \mathrm{C}$; Bhattacharya et al. 1992: $\left.780^{\circ} \mathrm{C}\right)$.

Further disintegration of the original granulite paragenesis can be followed numerically by studying the plagioclase-biotite corona around garnet porphyroblasts and the low-Ti rim of the matrix biotite as well as the white mica pseudomorphs after kyanite. Using three garnet grains together with the surrounding biotite and plagioclase, conditions of $730^{\circ} \mathrm{C}, 8.5 \mathrm{kbar}$, $700{ }^{\circ} \mathrm{C}, 6.7 \mathrm{kbar}$, and $640^{\circ} \mathrm{C}, 5.8$ kbar can be calculated using the Grt-Bt thermometer of Bhattacharya et al. (1992) as well as the GASP barometer. This suggests that the early granulite facies was followed by cooling and decompression.

The next metamorphic event is recorded by kyanite in different textural positions. Polymorphic transformation to sillimanite is the most common, while in presence of biotite suggests that kyanite broke down due to the reaction:

kyanite + biotite $=$ cordierite $+\mathrm{K}$-feldspar + spinel

If it reacted with garnet, the reaction was:

kyanite + garnet $=$ cordierite + plagioclase + spinel $\quad$ (7)

Taking in account the measured rim compositions of both garnet and biotite, the above reactions can be modelled for each microdomain independently in the $10 \mathrm{Grt}$ $+10 \mathrm{Ky}+1 \mathrm{H}_{2} \mathrm{O}$ and $10 \mathrm{Bt}+10 \mathrm{Ky}+1 \mathrm{H}_{2} \mathrm{O}$ systems, respectively using Theriak/Domino. Intersection of the three stability fields defines a relatively small $P-T$ window (Fig. 13), in which at around $640^{\circ} \mathrm{C}$ and $2.0 \mathrm{kbar}$ the model compositions of both cordierite $\left(\mathrm{Mg}_{0.66} \mathrm{Fe}_{0.33}\right)$ and spinel $\left(\mathrm{Mg}_{17} \mathrm{Fe}_{83}\right)$ fit well with the measured data. Using TWQ for modelling, there are numerous reactions in the appropriate KFASH system, among which three are independent: annite +3 kyanite $=3$ quartz $+\mathrm{K}$-feldspar + hercynite + $\mathrm{H}_{2} \mathrm{O}$ almandine +2 kyanite $=$ hercynite + Fe-cordierite
5 annite +15 kyanite $=5 \mathrm{~K}$-feldspar +9 hercynite + 3 Fe-cordierite $+5 \mathrm{H}_{2} \mathrm{O}$

Using these reactions and the measured mineral compositions, the equilibrium conditions can be estimated at $650 \pm 10^{\circ} \mathrm{C}$ and $3.1 \pm 0.1 \mathrm{kbar}$ (Fig. 12b). The few amphibole grains yield $\sim 660^{\circ} \mathrm{C}$ and $\sim 2 \mathrm{kbar}$, as well, using the approximation of Gerya et al. (1997). $P-T$ evolution of the granulite specimen is suggested in Fig. 10d.

\subsection{Deformation history}

Using only the microtextures of the orthogneiss mylonites to calculate the formation temperature, estimation may result in a rather broad interval. Crystal plastic deformation in quartz suggests $T_{\text {def }}>270^{\circ} \mathrm{C}$, while the coeval brittle behaviour of feldspar implies $T_{\text {def }}<450^{\circ} \mathrm{C}$ (Voll 1980; White et al. 1980; Passchier and Trouw 2005). A more accurate temperature may be computed using the geometry of the quartz-quartz grain boundaries, that is, by calculating the 
fractal dimension of sutures $(D)$ as suggested by Kruhl and Nega (1996). Image analysis of over 50 sutures was carried out using the material along a single borehole (Sz-N-2) that exposes several tens of metres of the mylonite zone. Additionally 15 samples representing the neighbouring drill holes were analysed. The results of the calculation are rather consistent, giving $D=1.23 \pm 0.06$, which suggests a $T_{\text {def }} \sim 430^{\circ} \mathrm{C}$ (Fig. 14). This datum is coherent with those derived from petrographic observations.

\section{Discussion}

\subsection{Evolution of the orthogneiss}

Detailed petrographic, geochemical, and geochronological data imply that metamorphic basement blocks of the studied segment of the Pannonian Basin consist of structural units of significantly different metamorphic and structural evolutions. The typical lithology in the deepest structural position reached by the drilling as well as in the northern flanks of the studied crystalline domes is orthogneiss
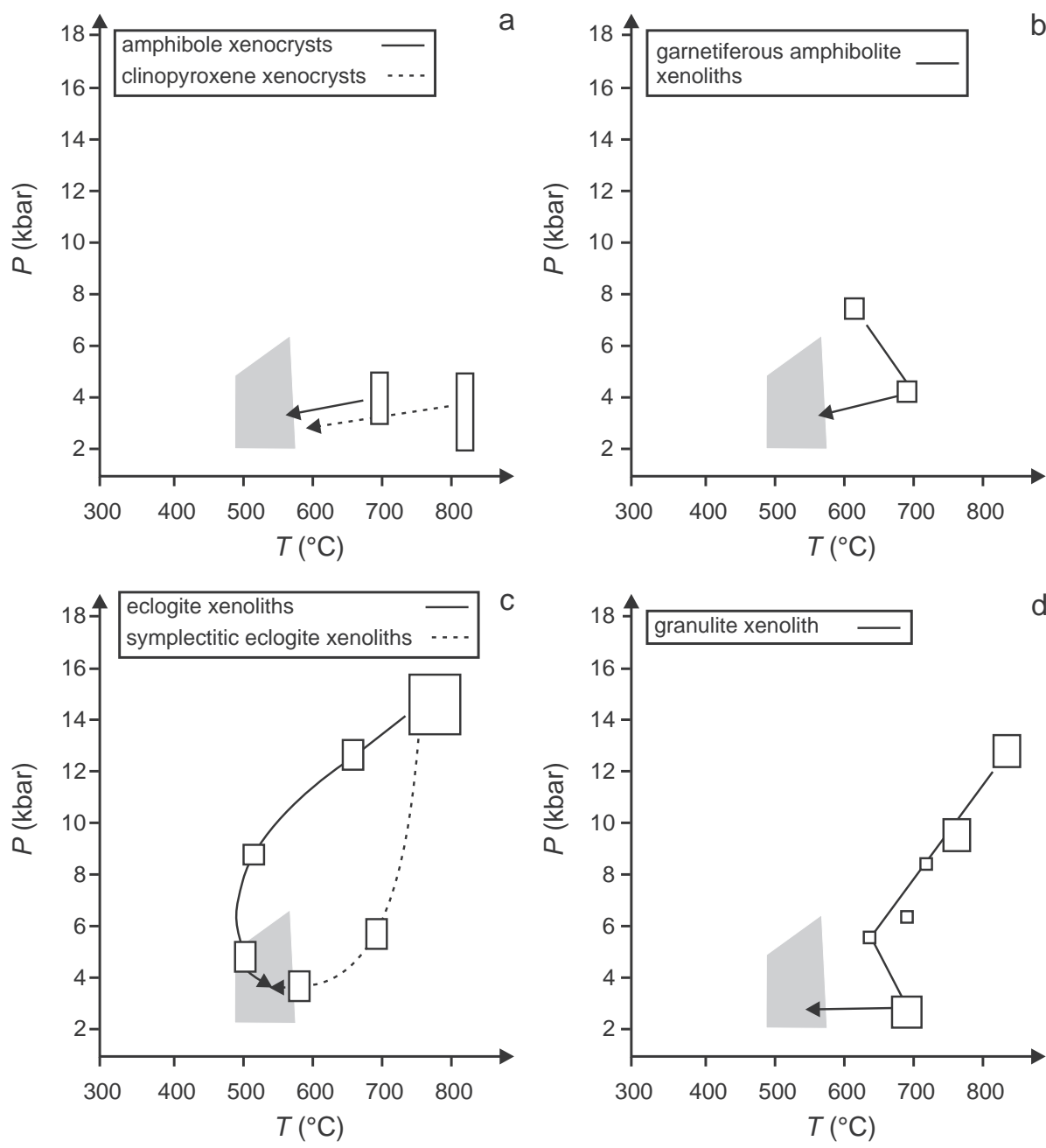

(Fig. 2). Among many others, Vernon and Collins (1988) regarded polygonal texture relics, observed in the studied rocks as the best distinctive indicator of orthogneiss. Its pre-metamorphic protolith was most probably granodiorite with metaluminous to peraluminous character (Fig. 7). The intrusive protolith is clearly indicated by several textural features, like the presence of myrmekitic and perthitic feldspar grains, polygonal quartz-feldspar textures, and idiomorphic accessory phases (Fig. 3). The most characteristic feature of the orthogneiss is the appearance of xenoliths and xenocrysts of diverse lithologies and genesis (Fig. 4).

Based only on the close genetic relationship between the host granitoid material and the mafic and ultramafic enclaves, Balázs et al. (1986) suggested that the studied lithology would be migmatite. They nevertheless did not report any textural evidence about the presence of potential leucosome in the studied rock samples. Also keeping in mind the extremely wide spectrum of chemical compositions and metamorphic evolutions from diverse xenoliths occurring even in the same borehole, an unmelted residual nebulite origin of these lenses can be excluded. Consequently, we suggest that this rock did not undergo partial melting and is not a migmatite.

Using all of the above data, a four-step evolution scheme can be modelled for the orthogneiss unit instead. The four defined stages are: (i) countryrock phase, (ii) intrusion phase, (iii) orthogneiss phase and (iv) mylonitic and post-mylonitic phase. These are detailed further below.

\subsubsection{Country-rock phase}

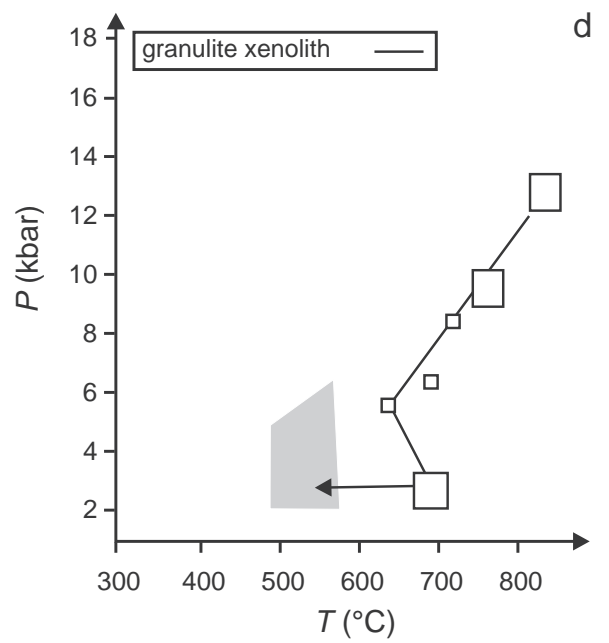

The presence of xenoliths (eclogite, amphibolite, granulite, serpentinite, marble) and xenocrysts (amphibole, garnet, clinopyroxene) of diverse com-

Fig. 10 Typical $P-T$ paths for diverse xenocrysts and xenoliths of the orthogneiss. Pale grey box denotes the assumed $P-T$ conditions of the orthogneiss formation. a - Amphibole and clinopyroxene xenocrysts. b - Garnet amphibolite xenoliths. c - Eclogite and symplectitic eclogite xenoliths. d - Granulite xenolith. Each box represents an individual thermobarometric datum. 
positions suggest significantly different metamorphic evolutions of the country rocks. The range they imply is especially wide with regard to the pressure extending from contact marbles up to $\sim 15 \mathrm{kbar}$ preserved by eclogite and granulite specimens. As a consequence, their early metamorphic evolution cannot be discussed in any common model. Most eclogites and the only granulite xenolith clearly provide textural and thermobarometric evidence for retrograde overprint down to greenschist/ lower amphibolite facies conditions prior to the granitic intrusion (Fig. 10). The same event, however, is not recorded by the symplectitic eclogite samples that record a retrograde evolution without any clear proof of reheating. Thus the typical $P-T$ paths of the eclogite xenoliths imply different exhumation mechanisms following the metamorphic peak. While for the symplectitic eclogite xenoliths an initial period of a near-isothermal decompression can be proved, the other group shows synchronous decreases of both $P$ and $T$ (Fig. 10c).

Garnet xenocrysts in diverse samples exhibit significantly different compositions and zoning patterns and so must be derived from rocks of various metamorphic evolutions. Nevertheless, in the absence of any other phases of the original mineral assemblages, there is no way to reconstruct these histories.

The oldest amphibole $\mathrm{K}-\mathrm{Ar}$ ages in amphibolite xenoliths vary around $334 \pm 13 \mathrm{Ma}$ (Balogh et al. 2009). As most samples were retrogressed at upper greenschist facies conditions prior to being picked up by the granitic magma, this age likely corresponds to this cooling event. It can be also assumed that in the largest xenoliths the
Table 3d Representative mineral compositions of the host orthogneisses and typical xenoliths - garnet $(12 \mathrm{O})$, sym: grain in the symplectitic eclogite (wt. \% and apfu; end members in mol. \%)

\begin{tabular}{|c|c|c|c|c|}
\hline & \multicolumn{2}{|c|}{$\begin{array}{l}\text { Eclogite } \\
\text { xenolith }\end{array}$} & \multirow{2}{*}{$\begin{array}{c}\begin{array}{c}\text { Granulite } \\
\text { xenolith }\end{array} \\
\text { Grt }\end{array}$} & \multirow{2}{*}{$\begin{array}{c}\text { Amphibolite } \\
\text { xenolith }\end{array}$} \\
\hline & Grt & Grt sym & & \\
\hline $\mathrm{SiO}_{2}$ & 39.13 & 39.06 & 36.77 & 38.32 \\
\hline $\mathrm{TiO}_{2}$ & 0.23 & 0.04 & 0.00 & 0.00 \\
\hline $\mathrm{Al}_{2} \mathrm{O}_{3}$ & 23.00 & 22.60 & 21.64 & 21.16 \\
\hline $\mathrm{FeO}$ & 18.16 & 20.59 & 34.58 & 26.40 \\
\hline $\mathrm{MnO}$ & 0.58 & 0.40 & 1.41 & 1.74 \\
\hline $\mathrm{MgO}$ & 8.90 & 7.74 & 4.74 & 2.71 \\
\hline $\mathrm{CaO}$ & 9.08 & 8.65 & 2.34 & 11.22 \\
\hline $\mathrm{Na}_{2} \mathrm{O}$ & 0.03 & 0.00 & 0.00 & 0.00 \\
\hline $\mathrm{K}_{2} \mathrm{O}$ & 0.01 & 0.00 & 0.01 & 0.00 \\
\hline Total & 99.13 & 99.07 & 101.48 & 101.55 \\
\hline $\mathrm{Si}$ & 2.97 & 3.00 & 2.91 & 2.99 \\
\hline $\mathrm{Ti}$ & 0.01 & 0.00 & 0.00 & 0.00 \\
\hline $\mathrm{Al}$ & 2.06 & 2.04 & 2.02 & 1.95 \\
\hline $\mathrm{Fe}$ & 1.15 & 1.32 & 2.29 & 1.72 \\
\hline $\mathrm{Mn}$ & 0.04 & 0.03 & 0.09 & 0.12 \\
\hline $\mathrm{Mg}$ & 1.01 & 0.88 & 0.56 & 0.32 \\
\hline $\mathrm{Ca}$ & 0.74 & 0.71 & 0.20 & 0.94 \\
\hline $\mathrm{Na}$ & 0.00 & 0.00 & 0.00 & 0.00 \\
\hline K & 0.00 & 0.00 & 0.00 & 0.00 \\
\hline Total & 7.99 & 7.98 & 8.08 & 8.03 \\
\hline Alm & 0.39 & 0.45 & 0.73 & 0.55 \\
\hline Sps & 0.01 & 0.01 & 0.03 & 0.04 \\
\hline Prp & 0.34 & 0.30 & 0.18 & 0.10 \\
\hline Grs & 0.25 & 0.24 & 0.06 & 0.30 \\
\hline
\end{tabular}
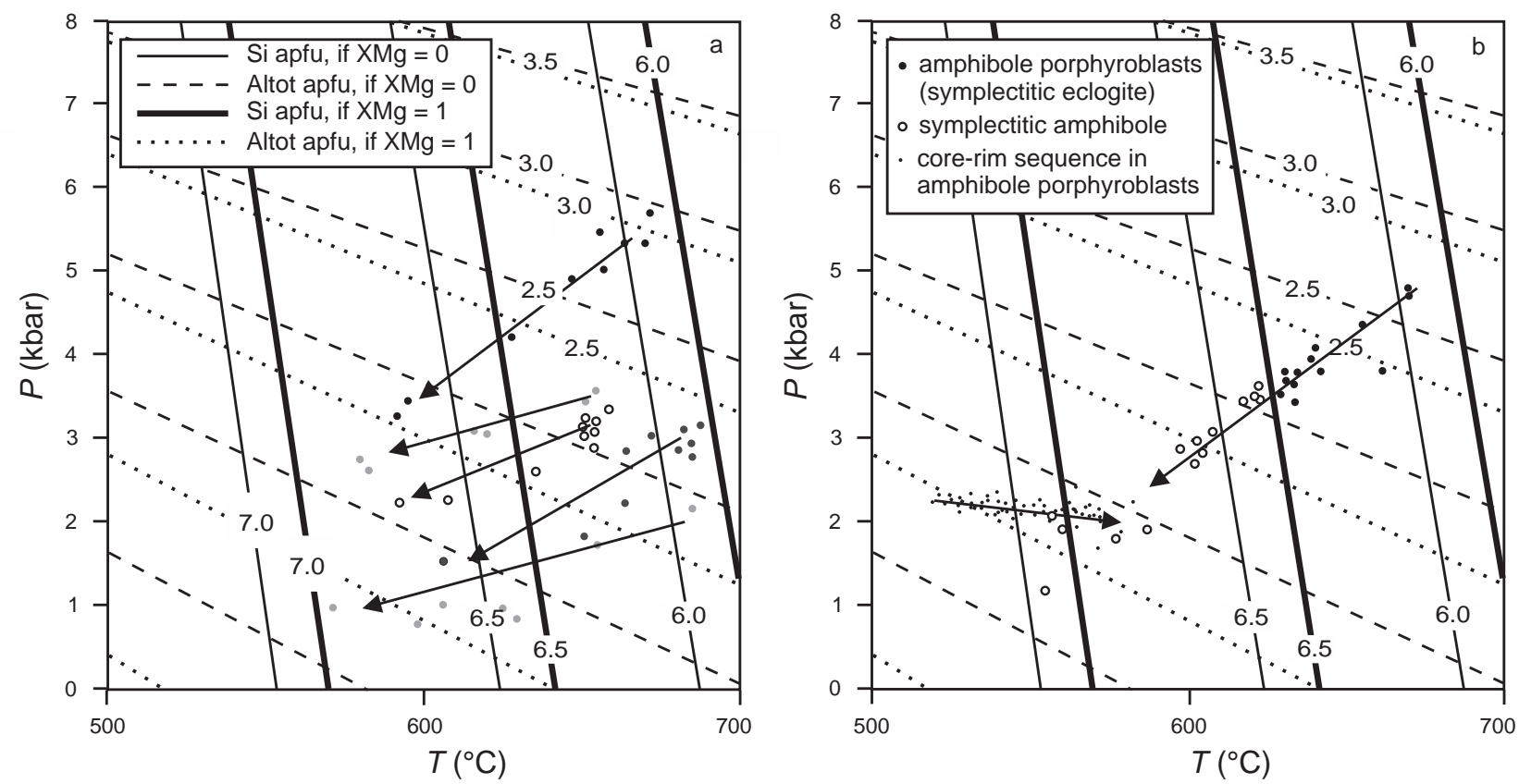

Fig. 11 Position of amphiboles on the diagram of Gerya et al. (1997). a - Amphibole xenocrysts in the orthogneiss; arrows denote core-rim sequence in five independent cases. $\mathbf{b}$ - Amphiboles of the eclogite xenoliths. 

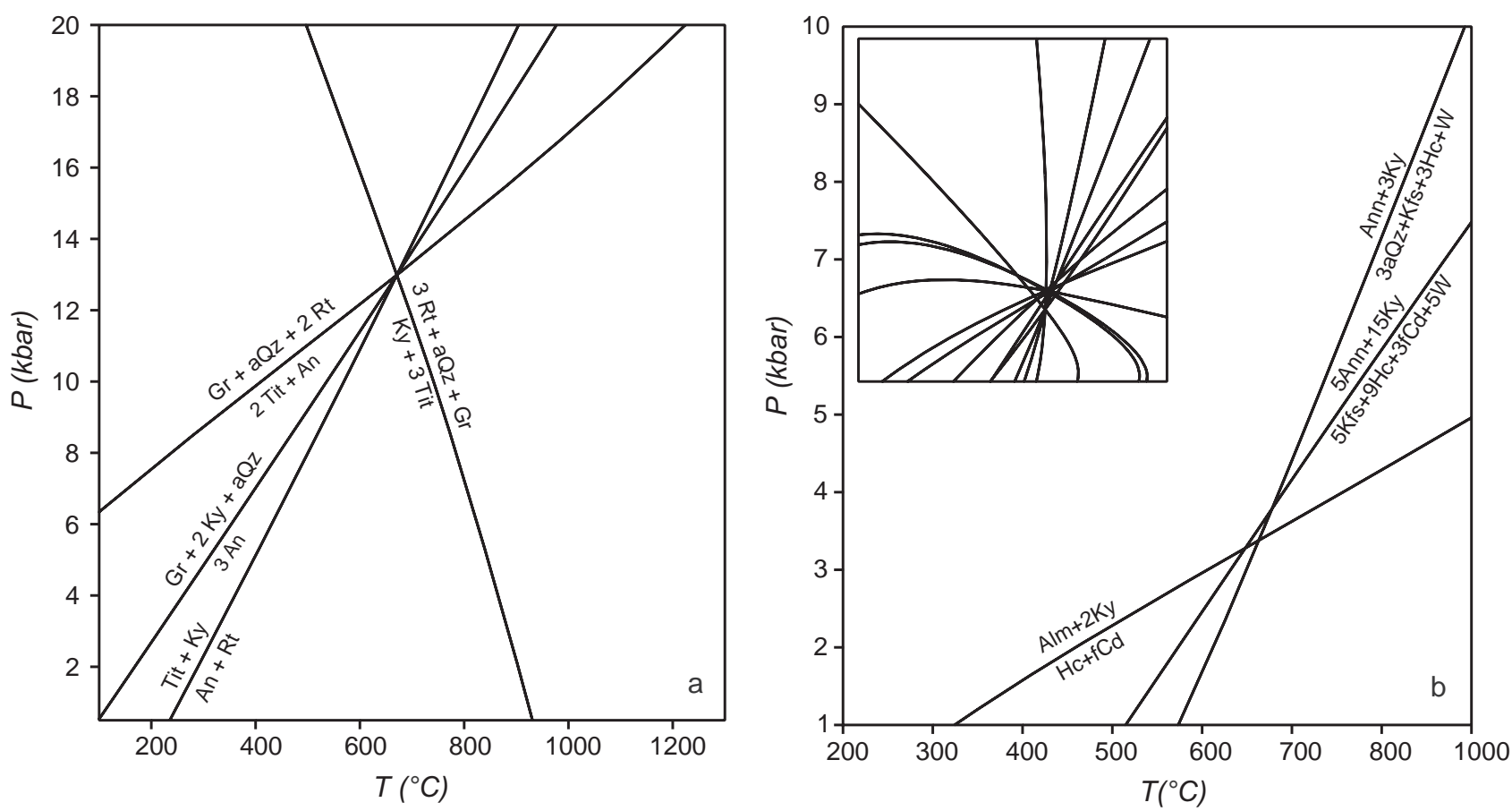

Fig. 12 Stability conditions in different xenoliths calculated using the intersection of independent reactions by the TWQ software (Berman 1991). $\mathbf{a}$ - Eclogite breakdown. $\mathbf{b}$ - Reheating of the felsic granulite (inset: position of all possible reactions in the model system).

later reheating event could not entirely reset the isotopic system and so this age can be also accepted as the youngest possible age of the xenoliths.

\subsubsection{Intrusion phase}

Textural evidence clearly indicates that the studied gneissose rocks are of igneous origin (Fig. 3). Not much information has been preserved that could indicate the physical conditions of the original magma. High-Ti biotite cores nevertheless preserved compositions suggesting a formation temperature consistent with granite crystallization at $\mathrm{T}>700^{\circ} \mathrm{C}$.
The genesis of amphibole and clinopyroxene xenocrysts are hard to reconstruct. In several cases they appear in contact with mafic xenoliths, but usually these crystals are just floating in the quartzofeldspathic matrix. Although the later situation is the most common, based on the observed tight textural relationship of xenocrysts and xenoliths, a common origin can be assumed. Therefore, we suggest that the xenocrysts either represent original constituents of the host xenoliths or evolved due to interaction between the xenoliths and the assimilating magma.

The composition of single amphibole crystals, however, does not confirm a residual origin as they exhibit almost identical chemistry in each studied case. The cores of all

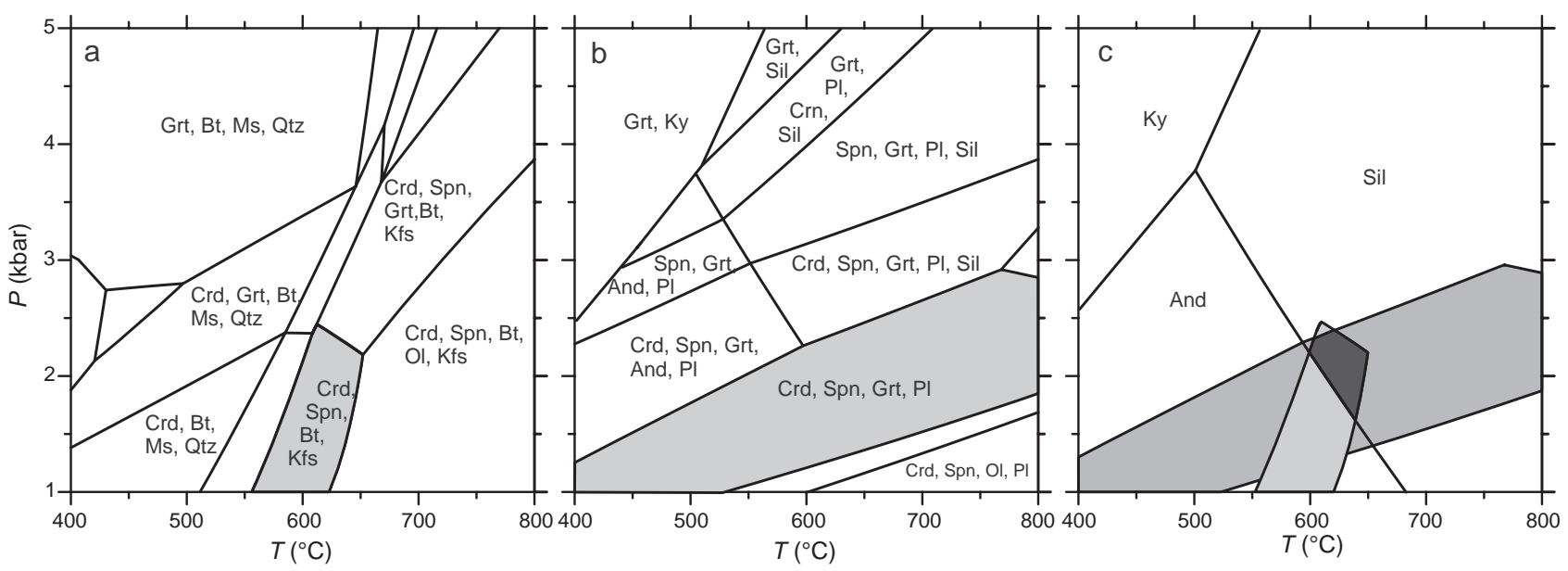

Fig. $13 P-T$ conditions of kyanite breakdown using three different assemblages as calculated by Theriak/Domino software. a - Kyanite-biotite microdomain. b-Kyanite-garnet microdomain. $\mathbf{c}$ - Intersection of all microdomains. 
Fig. 14a - Estimation of the fractal dimension values (D) of sutured grain boundaries measured on digitized images of quartz grains from orthogneiss mylonite samples, $\mathbf{b}$ - Temperature data calculated using the method of Kruhl and Nega (1996).
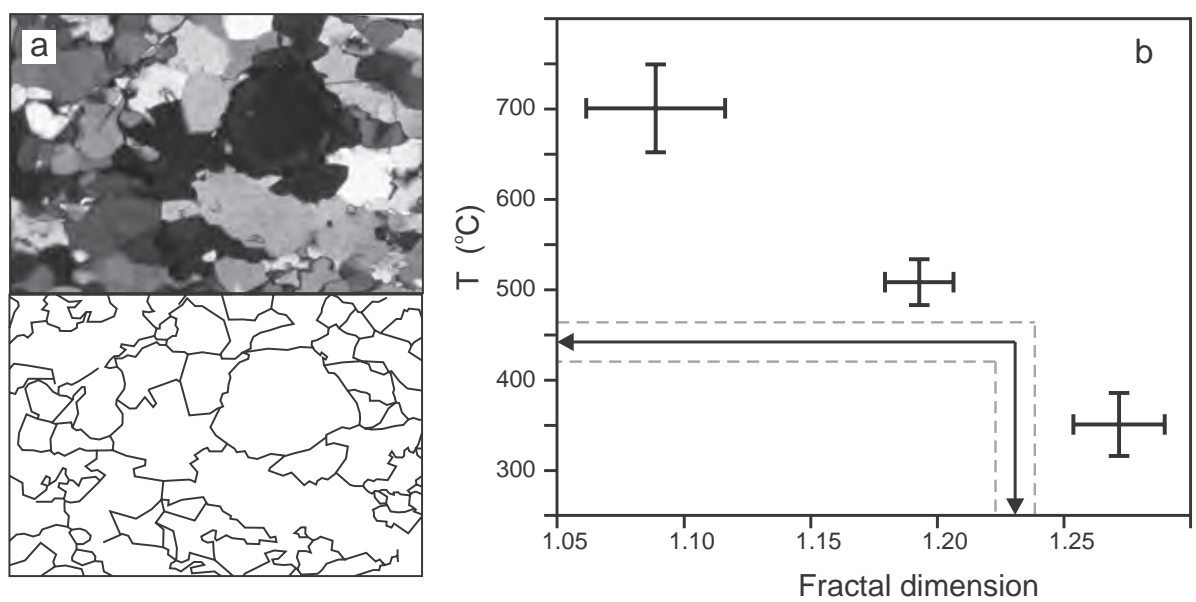

measured grains are hastingsite and tschermakite with maximal possible aluminium content in the $\mathrm{T}$ position $\left(\mathrm{Si}_{6} \mathrm{Al}_{2}\right)$, suggesting similarly high formation temperatures.

Although clinopyroxene is almost unknown in the xenoliths, it is among the most common xenocryst phases. Its composition shows $H T-L P$ formation conditions. All these facts together with the texture of randomly oriented anhedral to subhedral amphibole and clinopyroxene grains are, in general, typical of mafic hornfelses and prove the formation of the xenocrysts from the rims of the xenoliths. In this scenario, most xenoliths represent mafic rocks partially assimilated by the granitoid intrusion. Single-grain thermobarometric data of the amphibole crystals indeed confirm their origin due to thermal metamorphism.

The host granitic melt caused a thermal metamorphism on most xenoliths at $\mathrm{T} \geq \sim 680^{\circ} \mathrm{C}$ and $\mathrm{P} \sim 3 \mathrm{kbar}$. In marble xenoliths the appearance of lizardite in olivine pseudomorphs (Fig. 5) is a clear evidence for the previous presence of forsterite marble. Forsterite formation in metacarbonates and calc-silicates requires high $T$ and low $\mathrm{CO}_{2}$ fugacity and so is the most typical of contact-metamorphic rocks.

The felsic granulite sample studied preserved the characteristic cordierite-spinel symplectite around kyanite grains. An analogous microtexture has been reported around andalusite in pelitic xenoliths from granitoids (e.g. Pitra and de Waal 2001; Johnson et al. 2004). Such a replacement has always been interpreted as a prograde symplectite that suggests contact metamorphic overprint. The field gradient is well above $50{ }^{\circ} \mathrm{C} / \mathrm{km}$ for all the studied xenoliths; in the case of the cordierite-spinel corona it is even higher, $\sim 80^{\circ} \mathrm{C} / \mathrm{km}$. Considering data for all xenocrysts and xenoliths, the isobaric heating by the granitoid magma up to the hornblende hornfels-facies conditions is clearly evidenced.

\subsubsection{Orthogneiss phase}

Each studied paragenesis or grain in the orthogneiss regarded as metamorphic was formed at the final tem- perature of the thermal relaxation phase. All data suggest that the orthogneiss body in question represents a syn-tectonic granitoid intrusion. Its deformation, as well as the metamorphic overprint that resulted in the formation of a typical gneissic structure, had to take place during cooling of the granitoid body at $560-600^{\circ} \mathrm{C}$ and $\sim 3$ kbar. This $P-T$ range is rather well constrained by the Theriak/Domino model, by the metamorphic evolution of the xenoliths (Fig. 10) as well as by rim compositions of the matrix biotite (Fig. 9) and amphibole xenocrysts (Fig. 11). Also, two-feldspar thermometry confirms reequilibration at $\sim 600^{\circ} \mathrm{C}$.

Biotite and amphibole grains from the orthogneiss matrix yield $\mathrm{K}-\mathrm{Ar}$ ages of c. $295 \pm 11 \mathrm{Ma}$ and $297 \pm 11 \mathrm{Ma}$ (Balogh et al. 2009), interpreted as the age of recrystallization of the intrusive body and formation of the orthogneiss.

\subsubsection{Mylonite and post-mylonite phase}

Following the mylonitic event several intense deformation (cataclasis) and alteration (carbonate replacement and cementation) processes took place along the observed shear zone, which significantly overprinted the primary mineralogy and fabric of the mylonite (Fig. 6). Nevertheless, essential features of the early ductile event can be reconstructed based on the general appearance of the obvious kinematic indicators (mica fish or $\mathrm{S} / \mathrm{C}$ microstructure).

The recurrent occurrence of boudinaged quartz fragments along the mylonitic foliation suggests that the shear zone underwent ductile stretching that was parallel to the shearing vector at least during certain periods of its activity. Gillam et al. (2014) deduced similar ductile stretching and additional thinning perpendicular to a shear zone wall based on the common occurrence of shear band boudins and foliation boudinage along the Alpine mylonite zone (New Zealand). Nevertheless, the folded appearance of the mylonite in our case implies that not only stretching, but also shortening was evolved in the ductile shear zone inside the orthogneiss body. 

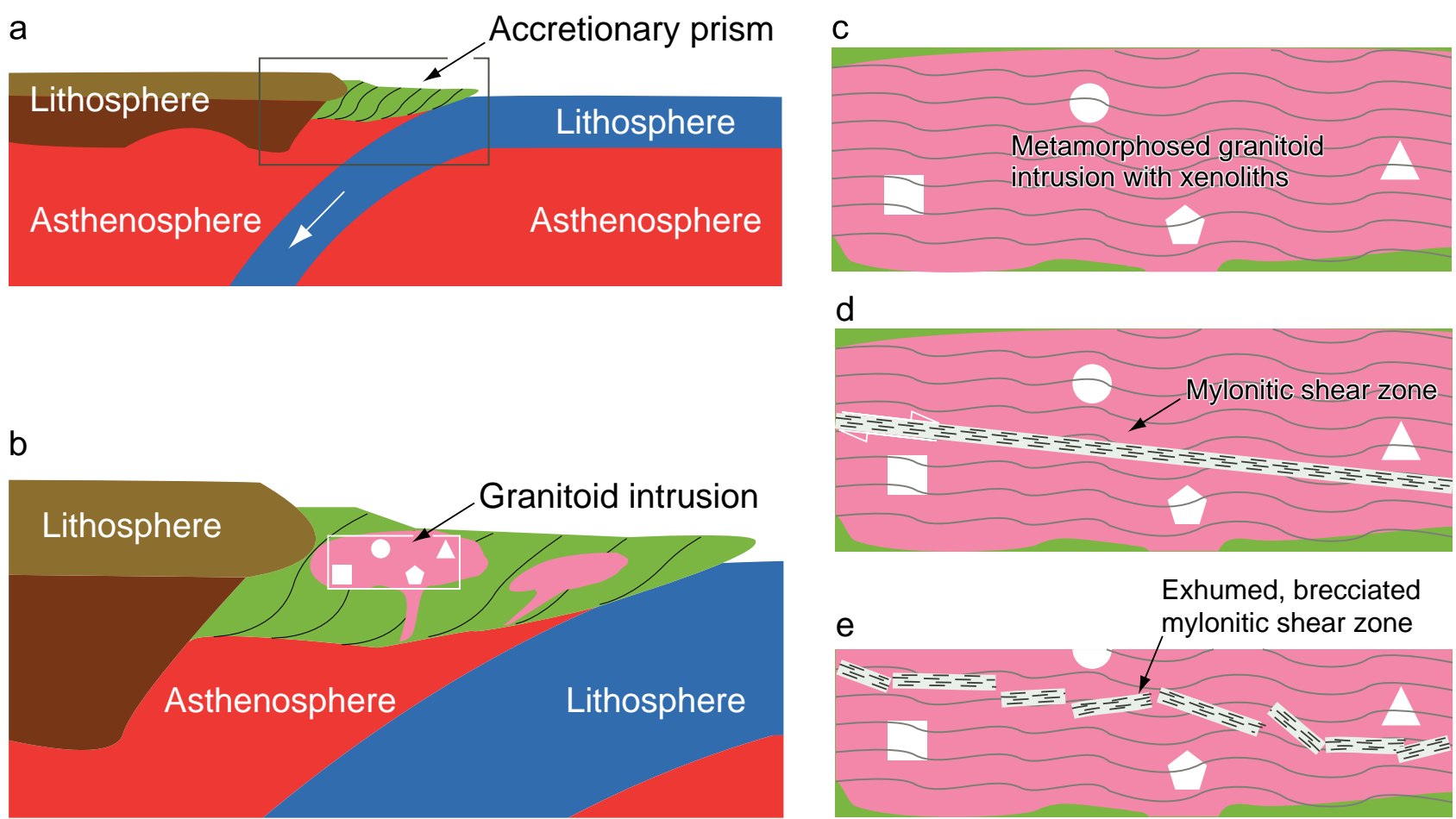

Fig. 15 Simplified proposed evolutionary history of the Körös Complex orthogneiss. a - Formation of a wide accretionary prism (Country-rock phase). $\mathbf{b}$ - The granitoid intrusion samples the accretionary prism (Intrusion phase). c - Cooling and coeval metamorphism of the syn-tectonic granitoid body and the enclosed xenoliths (Orthogneiss phase). d - Development of a ductile shear zone within the orthogneiss body (Mylonite phase). $\mathbf{e}$ - Exhumation and brecciation of the orthogneiss body (Post-mylonite phase).

Both textural observations and thermometric calculations confirm that mylonitic deformation of the orthogneiss block happened along the retrograde pathway at $c .430^{\circ} \mathrm{C}$. As the undeformed orthogneiss protolith commonly does not contain white mica, the muscovite separated and measured from the most intensely deformed orthogneiss mylonite probably formed due to this deformation event at $280 \pm 11 \mathrm{Ma}$ (Balogh et al. 2009).

Rock fragments of the cataclasites that form the fault zones inside the orthogneiss body are mainly of mylonitized orthogneiss, suggesting that mylonitic shear zones became overprinted at shallower depth by a subsequent brittle deformation event, probably during the same prolonged displacement (Jefferies et al. 2006).

\subsection{Geodynamic consequences}

The formation of orthogneiss from a peraluminous granitoid protolith that contains xenoliths of different $P-T$ evolutions is characteristic of subduction-accretionary orogenic belts (e.g. Ochsner 1993). According to this model (Fig. 15) the permanent sediment transport during subduction results in the development of a wide accretionary prism that tends to grow oceanward (Ochsner 1993). As a consequence, the subduction front itself retreats as well, resulting in the presence of ascending, relatively low-density blocks of the subducted slab dock- ing under the prism (Cowan and Silling 1978), enriching its material with rock fragments of mafic and ultramafic rocks of different metamorphic conditions. Due to the heat of the ascending mantle-derived basaltic melts, the accretionary complex can partially melt at deep crustal levels, mainly producing granodiorites with subaluminous to peraluminous compositions (Jiang et al. 2016). Coevally, the heat transport may cause granulite-facies metamorphism in the sedimentary piles of the accretionary prism (Castro et al. 1991). As the granitoid magmas intrude the accretionary prism, they pick up rock fragments of different compositions, which appear as xenoliths in the later magmatic body (Zurbriggen et al. 1997).

Accepting the above subduction-accretionary model for the orthogneiss block of the Körös Complex, the amphibolite, eclogite, and granulite (and numerous other) xenoliths would represent the material of the previous mélange of an accretionary prism. According to this scenario, heating up of the wedge as well as the coinciding granitoid magmatism may be responsible for the HT-LP metamorphic overprint $\left(\sim 680^{\circ} \mathrm{C}, \sim 3 \mathrm{kbar}\right)$ detected in each studied xenolith type. Metamorphic overprint and formation of the main schistosity of the whole orthogneiss complex developed following a close-to-isobaric cooling of the pluton to $\sim 580^{\circ} \mathrm{C}$.

Existing geochronological data (Tab. 1; Balogh et al. 2009) of the orthogneiss complex can be interpreted in 
the frame of the suggested model. The bimodal $\mathrm{K}-\mathrm{Ar}$ age distribution characteristic of the OG unit confirms the petrological explanation that the xenoliths indeed do not belong to the host orthogneiss genetically but rather represent exotic blocks of diverse origins. Thermobarometric analysis of the xenoliths clearly indicates reheating, probably caused by the granitoid melt. One can assume that in the case of large enough xenolith blocks this thermal effect could not significantly modify the original $\mathrm{K}-\mathrm{Ar}$ ages, and so these blocks preserve an age of $\sim 330 \mathrm{Ma}$. This datum probably records the minimum age when the xenoliths cooled down in the accretionary wedge. On the other hand, single amphibole xenocrysts and biotite grains of the orthogneiss all exhibit the age of the last orthogneiss cooling, $\sim 295 \mathrm{Ma}$.

Further along the retrograde pathway the orthogneiss body suffered mylonitic deformation at $\sim 430{ }^{\circ} \mathrm{C}$, as computed using quartz suture thermometry (Fig. 14). The age of this event is $\sim 280 \pm 11 \mathrm{Ma}$ (Balogh et al. 2009). A rather similar age (273 $\pm 7 \mathrm{Ma}$, garnet $\mathrm{Sm}-\mathrm{Nd})$ was previously reported from an orthogneiss mylonite zone from another subregion of the basement by LelkesFelvári et al. (2005). These data point to the importance of the extension of the Variscan lithosphere during the Early Permian in the study area and probably in a significant part of the Tisza Block. This statement is further confirmed by zircon U-Pb ages $(288 \pm 7 \mathrm{Ma})$ of extension-related rhyolites common throughout the Pannonian Basin (Varga et al. 2013). How this structural event can be linked to the basin formation widespread in the European Variscan Belt (e.g. Lützner et al. 2003; McCann et al. 2006; Cassinis et al. 2012) should still be studied in more detail.

\section{Conclusions}

Characteristic textures and mineral assemblage of the Körös Complex orthogneiss are identical in the whole studied area. The most conspicuous petrographic characteristic of the orthogneiss is the presence of various types of xenoliths (mainly mafic in composition), which preserve a wide spectrum of early metamorphic evolutions, especially concerning pressure conditions and the effect of a $L P-H T$ overprint by the host granitoid magma. Thermobarometric calculations suggest metamorphism of the syn-tectonic metaluminous to peraluminous quartz monzodiorite to granodiorite intrusion at $580-600{ }^{\circ} \mathrm{C}$ along the cooling pathway. Origin and evolution of the whole orthogneiss body fits well with the subduction-accretionary geodynamic model. According to this interpretation, heat from basaltic injections caused partial melting of the accretionary wedge resulting in granodioritic magmas. As they intruded the accretionary prism itself, they could pick up rock fragments of different compositions, which appear as xenoliths in the metaigneous body.

Acknowledgements. The co-operation and discussion with J. Zachar is acknowledged. The electron microprobe laboratory at the University of Bern was sponsored by the Schweizerische Nationalfonds (No.: 21-26579.89). Thorough reviews of Prokop Závada, Martin Racek and an anonymous reviewer are thanked. P. Hasalová is acknowledged for her editorial work on the manuscript.

\section{References}

Albu I, PÁPA A (1992) Application of high-resolution seismics in studying reservoir characteristics of hydrocarbon deposits in Hungary. Geophysics 57: 1068-1088

ALмÁsI I, Tóтн J (2000) Interpretation of observed fluid potential patterns in a deep sedimentary basin under tectonic compression: Hungarian Great Plain, Pannonian Basin. Geofluids 1: 11-36

Árkai P, Horváth P, NaGy G (1999) A clockwise P-T path from the Variscan basement of the Tisza Unit, Pannonian Basin, Hungary. Geol Croatica 52: 109-117

Balázs E, Cserepes-Meszéna B, Nusszer A, SziliGYÉMÁNT P (1986) An attempt to correlate the metamorphic formations of the Great Hungarian Plain and the Transylvanian Central Mountains (Muntii Apuseni). Acta Geol Hung 29: 317-320

Balogh K, Tóth TM, Dunkl I, Scherrer N (2009) Geochronology of the polymetamorphic basement in the Szeghalom and Mezösas-Furta Highs. In: TóTH TM (ed) Magmás és metamorf képzödmények a Tiszai Egységben. GeoLitera, Szeged, pp 147-160 (in Hungarian)

BERMAN RG (1988) Internally-consistent thermodynamic data for minerals in the system $\mathrm{Na}_{2} \mathrm{O}-\mathrm{K}_{2} \mathrm{O}-\mathrm{CaO}-\mathrm{MgO}-$ $\mathrm{FeO}-\mathrm{Fe}_{2} \mathrm{O}_{3}-\mathrm{Al}_{2} \mathrm{O}_{3}-\mathrm{SiO}_{2}-\mathrm{TiO}_{2}-\mathrm{H}_{2} \mathrm{O}-\mathrm{CO}_{2}$. J Petrol 29: 445-522

BERMAN RG (1991) Thermobarometry using multi-equilibrium calculations: a new technique, with petrological applications. Canad Mineral 29: 833-855

Bhattacharya A, Mohanty L, Maji A, Sen SK, Raith M (1992) Non-ideal mixing in the phlogopite annite binary: constraints from experimental data on $\mathrm{Mg}-\mathrm{Fe}$ partitioning and a reformulation of the biotite-garnet thermometer. Contrib Mineral Petrol 111: 87-93

BUCHER K (1987) A recalibration of the chlorite-biotitemuscovite geobarometer. Contrib Mineral Petrol 96: 519-522

Cassinis G, Perotti CR, Ronchi A (2012) Permian continental basins in the Southern Alps (Italy) and periMediterranean correlations. Int J Earth Sci 101: 129-157

Castro A, Moreno-Ventas I, De la Rosa JD (1991) H-type (hybrid) granitoids: a proposed revision of the 
granite-type classification and nomenclature. Earth Sci Rev 31: 237-253

Chatterjee ND, Froese E (1975) A thermodynamic study of the pseudobinary join muscovite-paragonite in the system $\mathrm{NaAlSi}_{3} \mathrm{O}_{8}-\mathrm{KAlSi}_{3} \mathrm{O}_{8}-\mathrm{Al}_{2} \mathrm{O}_{3}-\mathrm{SiO}_{2}-\mathrm{H}_{2} \mathrm{O}$. Amer Miner 60: 985-993

Coleman RG, Lee DE, Beatty LB, Brannock WW (1965) Eclogites and eclogites: their differences and similarities. Geol Soc Am Bull 76: 483-508

CowAN DS, SiLLING RM (1978) A dynamic, scaled model of accretion at trenches and its application for the tectonic evolution of subduction complexes. J Geophys Res 83: $5389-5396$

Csontos L, Nagymarosy A, Horváth F, Kovác M (1992) Tertiary evolution of the intra-Carpathian areas: a model. Tectonophysics 208: 221-241

Dasgupta S, Sengupta P, Guha D, Fukuoka M (1991) A refined garnet-biotite $\mathrm{Fe}-\mathrm{Mg}$ exchange geothermometer and its application in amphibolites and granulites. Contrib Mineral Petrol 109: 130-137

DeBOn F, Le Fort P (1983) A chemical-mineralogical classification of common plutonic rocks and associations. Trans Roy Soc Edinb, Earth Sci 73: 135-149

DE CAPITANI C (1994) Gleichgewichts-Phasendiagramme: Theorie und Software. Beihefte zum Eur J Mineral, 72. Jahrestagung der Deutschen Mineralogischen Gesellschaft, 6: 48

de Capitani C, Brown TH (1987) The computation of chemical equilibrium in complex systems containing non-ideal solutions. Geochim Cosmochim Acta 51: $2639-2652$

de Capitani C, Petrakakis K (2010) The computation of equilibrium assemblage diagrams with Theriak/Domino software. Amer Miner 95: 1006 -1016

Fuhrman ML, Lindsley DH (1988) Ternary-feldspar modeling and thermometry. Amer Miner 73: 201-215

Ganguly J, SaXena SK (1984) Mixing properties of alumosilicate garnets: constrains from natural and experimental data and application to geothermo-barometry. Amer Miner 69: 88-97

Gerya TV, Perchuk Ll, Triboulet C, Audren C, Sez'ko AI (1997) Petrology of the Tumanshet Zonal Metamorphic Complex, Eastern Sayan. Petrology 5: 503-533

Gillam BG, Little TA, Smith E, Toy VG (2014) Reprint of extensional shear band development on the outer margin of the Alpine mylonite zone, Tatare Stream, Southern Alps, New Zealand. J Struct Geol 64: 115-134

Graham CM, Powell R (1984) A garnet-hornblende geothermometer: calibration, testing, and application to the Pelona Schist, Southern California. J Metamorph Geol 2: 13-31

Green TH, Hellmann PL (1982) Fe-Mg partitioning between coexisting garnet and phengite at high pressure, and comments on garnet-phengite geothermometer. Lithos 15: $253-266$
Henry DJ, Guidotti CV, Thomson JA (2005) The Ti-saturation surface for low-to-medium pressure metapelitic biotite: implications for geothermometry and Ti-substitution mechanisms. Amer Miner 90: 316-328

Holland TJB, Blundy J (1994) Non-ideal interactions in calcic amphibole and their bearing on amphibole-plagioclase thermometry. Contrib Mineral Petrol 116: 433-447

JefFeries SP, Holdsworth RE, Shimamoto T, TaKagi H, Lloyd GE, SpIERs CJ (2006) Origin and mechanical significance of foliated cataclastic rocks in the cores of crustal- scale faults: examples from the Median Tectonic Line, Japan. J Geophys Res 111: B12303

Jiang YD, Schulmann K, Sun M, ŠTíPSKá P, GuY A, JANOUŠEK V, LEXA O, YUAN C (2016) Anatexis of accretionary wedge, Pacific-type magmatism, and formation of vertically stratified continental crust in the Altai Orogenic Belt. Tectonics 35: 3095-3118

Johnson T, Brown M, Gibson R, Wing B (2004) Spinelcordierite symplectites replacing andalusite: evidence for melt-assisted diapirism in the Bushveld Complex, South Africa. J Metamorph Geol 22: 529-545

Juhász A, Tóth TM, Ramseyer K, Matter A (2002) Connected fluid evolution in fractured crystalline basement and overlying sediments, Pannonian Basin, SE Hungary. Chem Geol 182: 91-120

KoHN MJ, SPEAR FS (1990) Two new geobarometers for garnet amphibolites, with application to southeastern Vermont. Amer Miner 75: 89-96

Kovács S, SZederkéNyi T, HaAs J, Buda Gy, CsászÁr G, NAGYMARosy A (2000) Tectonostratigraphic terranes in the pre-Neogene basement of the Hungarian part of the Pannonian area. Acta Geol Hung 43: 225-328

Krogh EJ, RÅHeIm A (1978) Temperature and oressure dependence of $\mathrm{Fe}-\mathrm{Mg}$ partitioning between garnet and phengite, with particular reference to eclogites. Contrib Mineral Petrol 66: 75-80

KruHL JH, Nega M (1996) The fractal shape of sutured quartz grain boundaries: application as a geothermometer. Geol Rundsch 85: 38-43

Leake BE, Woollley AR, Arps CES, Birch WD, Gilbert MC, Grice JD, Hawthorne FC, Kato A, Kisch HJ, Krivovichev VG, Linthout K, LaIrd J, Mandarino JA, Maresh WM, Nickel EH, Rock NMS, SchumACHER JC, SMith DC, Stephenson NCN, UngaretTi L, WhitTaKer EJW, Youzhi G (1997) Nomenclature of amphiboles: report of the Subcommittee on Amphiboles of the International Mineralogical Commission on New Minerals and Mineral Names. Mineral Mag 61:295-321

Lelkes-Felvári Gy, Schuster R, Frank W, Sassi R (2005) Metamorphic history of the Algyö High (Tisza Mega-unit, basement of Great Hungarian Plain) - a counterpart of crystalline units of the Koralpe-Wölz nappe system (Austroalpine, Eastern Alps). Acta Geol Hung 48: 371-394 
LÖRINCZ DK (1996) Determination of stress-field history on the basis of multiphase tectonism identified in seismic profiles in the western part of the Szolnok flysh belt. Magyar Geofizika 37: 228-246 (in Hungarian)

LÜTZner H, LitTManN S, MädLER J, Romer RL, SchneIDER JW (2003) Radiometric and biostratigraphic data of the Permocarboniferous reference section Thüringer Wald. In: Wong TE (ed) Proceedings of the $X^{\text {th }} I n-$ ternational Congress on Carboniferous and Permian Stratigraphy. Edita, Utrecht, pp 161-174

McCann T, Pascal C, Timmerman MJ, Krzywiec P, Lopez-Gomez J, Wetzel A, Krawczyk CM, Rieke H, LAmarche J (2006) Post-Variscan (end CarboniferousEarly Permian) basin evolution in Western and Central Europe. In: Gee DG, Stephenson RA (eds) European Lithosphere Dynamics. Geological Society, London, Memoirs, 32: 355-388

Majumder S, Mamtani MA (2009) Fractal analysis of quartz grain boundary sutures in a granite (Malanjkhand, central India) - Implications to Infer Regional Tectonics. J Geol Soc India 73: 309-319

MANDELBROT BB (1967) How long is the coast of Britain? Statistical self-similarity and fractional dimension. Science 156: 636-638

Maniar PD, PicColi PM (1989) Tectonic discrimination of granitoids. Geol Soc Am Bull 101: 635-643

Massonne HJ, Schreyer W (1987) Phengite geobarometry based on limiting assemblage with K-feldspar, phlogopite and quartz. Contrib Mineral Petrol 96: 212-224

Meyre C, de Capitani C, Partzsch JH (1997) A ternary solid solution model for omphacite and its application to geothermobarometry of eclogites from the Middle Adula Nappe (Central Alps, Switzerland). J Metamorph Geol 15: 687-700

Molnár L, Tóth TM, Schubert F (2015) Structural controls on the petroleum migration and entrapment within faulted basement blocks of the Szeghalom Dome (Pannonian Basin, SE Hungary). Geol Croatica 68: 247-259

Nelson RA (2001) Geologic Analysis of Naturally Fractured Reservoirs. Gulf Publishing Co., Boston, pp 1-332

Nimis P, TAYlor W (2000) Single clinopyroxene thermobarometry for garnet peridotites. Part I. Calibration and testing of a Cr-in-Cpx barometer and an enstatite-in-Cpx thermometer. Contrib Mineral Petrol 139: 541-554

OCHSNER A (1993) U-Pb Geochronology of the Upper Proterozoic-Lower Paleozoic Geodynamic Evolution in the Ossa-Morena Zone (SW Iberia): Constraints on the Timing of the Cadomian Orogeny. Unpublished PhD thesis, ETH Zürich, pp 1-249

Pap S, Söreg V, Papné Hasznos I (1992) Problems of the Dévaványa-south metamorphic basement $\mathrm{HC}$ reservoir a case study. Geophys Trans 37: 211-228 (in Hungarian)

Passchier CS, Trouw RAJ (2005) Microtectonics. Springer, Berlin, pp 1-366
Pearce JA, Harris NBW, Tindle AG (1984) Trace element discrimination diagrams for the tectonic interpretation of granitic rocks. J Petrol 25: 956-983

Pitra P, De WaAl SA (2001) High-temperature, lowpressure metamorphism and development of prograde symplectites, Marble Hall Fragment, Bushveld Complex (South Africa). J Metamorph Geol 19: 311-325

PlyusNina LP (1982) Geothermometry and geobarometry of plagioclase-hornblende bearing assemblages. Contrib Mineral Petrol 80: 140-146

Pogácsás Gy, Lakatos L, Barvitz A, Vakarcs G, Farkas Cs (1989) Pliocene-Quaternary displacements in the Great Hungarian Plane. Ált Földt Szemle 24: 149-169 (in Hungarian)

PosGay K, SzentGyöRgYI K (1991) Displaced transversal shear zone across the lithosphere in the eastern part of the Pannonian Basin. Magyar Geofizika 32: 1-15 (in Hungarian)

Posgay K, Takács E, Szalai I, Bodoky T, Hegedüs E, JáNVÁRINÉ KI, TÍMÁr Z, VARGa G, BércZi I, SZALAY Á (1996) International deep reflection survey along the Hungarian Geotraverse. Geophys Trans 40: 1-44

Schubert F, Tóth TM (2001) Structural evolution of mylonitized gneiss zone from the northern flank of the Szeghalom Dome (Pannonian Basin, SE Hungary). Acta Mineral Petrogr 42: 59-64

SCHUbert F, Diamond LW, Tóth TM (2007) Fluid inclusion evidence of petroleum migration through a buried metamorphic dome in the Pannonian Basin, Hungary. Chem Geol 244: 357-381

SPEAR FS, Kimball KL (1984) RECAMP - A FORTRAN IV program for estimating $\mathrm{Fe}^{3+}$ contents in amphiboles. Comput and Geosci 10: 317-325

SZEDERKÉNyI T, ÁrKAI P, LELKEs-Felvári Gy (1991) Crystalline groundfloor of the Great Hungarian Plain and South Transdanubia, Hungary. Serbian Academy of Sciences and Arts, Academic Conferences 62: 261-273

SZEPESHÁZY K (1973) Relationship between metamorphic formations of the Great Hungarian Plain and the Carpathians. Ált Földt Szemle 3: 5-57 (in Hungarian)

Takahashi M, Nagahama H, Masuda T, Fujimura A (1998) Fractal analysis of experimentally, dynamically recrystallized quartz grains and its possible application as a strain rate meter. J Struct Geol 20: 269-275

TARi G, Horváth F, Rumpler J (1992) Styles of extension in the Pannonian Basin. Tectonophysics 208: 203-219

Tari G, Dövényi P, Dunkl I, Horváth F, Lenkey L, Stefanescu M, Szafián P, Tóth T (1999) Lithospheric structure of the Pannonian Basin derived from seismic, gravity and geothermal data. In: Durand B, Jolivet L, Horváth F, SÉranne M (eds) The Mediterranean Basins: Tertiary Extension within the Alpine Orogen. Geological Society, London, Special Publications 156: 215-250 
TARI G, Horváth F (2006) Alpine evolution and hydrocarbon geology of the Pannonian Basin: an overview. In: Golonka J, PICHA FJ (eds) The Carpathians and their Foreland: Geology and Hydrocarbon Resources. AAPG Memoirs 84: 605-618

Tо́тн TM (1995) Retrograded eclogite in the crystalline basement of Tisza Unit, Hungary. Acta Mineral Petrogr 36: $117-128$

Tóтн TM (1997) Retrograded eclogite from the Körös Complex (Eastern Hungary): records of a two-phase metamorphic evolution in the Tisia composite terrane. Acta Mineral Petrogr 38: 51-63

Tóтн TM (2008) Fractured, Metamorphic Fluid Reservoirs in the Basement of the Great Hungarian Plain. Unpublished DSc thesis, Hungarian Academy of Sciences, Budapest, pp 1-318 (in Hungarian)

Tóтн TM (2012) Geochemistry of Variscan amphibolites from the metamorphic basement of the Körös Complex (Tisza Block, Hungary). CJEES 7: 5-18

Tóth TM, ZACHAR J (2006) Petrology and deformation history of the metamorphic basement in the MezösasFurta Crystalline High (SE Hungary). Acta Geol Hung 49: $165-188$

Tóth TM, Schubert F, Zachar J (2000) Neogene exhumation of the Variscan Szeghalom Dome, Pannonian Basin, E. Hungary. Geol J 35: 265-284

Tóth TM, Kedves M, Schubert F (2003) Exhumation of the metamorphic basement of the Pannonian Basin (Szeghalom Dome, SE Hungary): palynological constraints. Földt Közl 133: 547-562 (in Hungarian)

Tóth TM, Hollós Cs, Szücs É, Schubert F (2004) Conceptual fracture network model of the crystalline basement of the Szeghalom Dome (Pannonian Basin, SE Hungary). Acta Geol Hung 47: 19-34

TóTH TM, REDLERNÉ TÁTRAI M, KuMMER I (2008) Structural evolution of the Szeghalom metamorphic high based on petrological and seismic data. Magyar Geofizika 49: 143-151 (in Hungarian)

Tóth TM, Földes T, VÁsÁrhelyi B, VÁN P, Kiss B, KuRGYiS P, LAKos B (2010) Integrated evaluation of petrologic, petrophysical and geophysical data of the Mezösas-W fractured metamorphic HC-reservoir. MOL Sci Mag 2010: 74-81 (in Hungarian)

TruSoft International Inc (1997) Benoit 1.0. Trusoft St Petersburg, Florida

Varga A, Dabi G, Raucsik B, Bajnóczi B, Schubert F, PÁl-Molnár E, Hidasi T (2013) Late Variscan depositional environments in Southern Transdanubia: relationships among the Korpád sandstone, Gyürüfü rhyolite and Cserdi conglomerate formations. In: DÁLYAY V, SÁMSON M, HÁmos G (eds) IV. Közettani és Geokémiai Vándorgyülés Kiadványa. Pécs, pp 7-11 (in Hungarian)

Vass I, Tóth TM, Szanyi J, Kovács B (2018) Hybrid numerical modelling of fluid and heat transport between the overpressured and gravitational flow systems of the Pannonian Basin. Geothermics 72: 268-276

VERnON RH, CoLlins WJ (1988) Igneous microstructures in migmatites. Geology 16: $1126-1129$

Voll G (1980) Ein Querprofil durch die Schweizer Alpen vom Vierwaldstatter See zur Wurzelzone-Strukturen und ihre Entwicklung durch Defomationsmechanismen wichtiger Minerale. Neu Jb Geol Paläont, Abh 160: 321-335

White SH, Burrows SE, Carreras J, Shaw ND, HumPHREYS FJ (1980) On mylonites in ductile shear zones. J Struct Geol 2: 175-187

Whitney DL, Evans BW (2010) Abbreviations for names of rock-forming minerals. Amer Miner 95: 185-187

ZACHAR J, TóTH TM (2001) Myrmekite-bearing gneiss from the Szeghalom Dome (Pannonian Basin, SE Hungary). Part II.: Origin and spatial relationships. Acta Mineral Petrogr 42: 39-43

ZACHAR J, TóTH TM (2003) Xenoliths of various metamorphic evolutions in the Déva orthogneiss (Tisza Block, Hungary). J Czech Geol Soc 48: 137-138

ZACHAR J, TóTH TM, JANÁK M (2007) Kyanite eclogite from the Jánoshalma High, crystalline basement of the Tisza Unit, southern Hungary. Lithos 99: 249-265

Zurbriggen R, Franz L, Handy MR (1997) Pre-Variscan deformation, metamorphism and magmatism in the Strona-Ceneri Zone (southern Alps of northern Italy and southern Switzerland). Schweiz Mineral Petrogr Mitt 77: 361-380 